\title{
A NEW PERSPECTIVE ON THE INTERNATIONAL CRIMINAL COURT: WHY THE RIGHT SHOULD EMBRACE THE ICC AND HOW AMERICA CAN USE IT
}

\author{
Ron Sievert ${ }^{*}$
}

Table of Contents

Synopsis ................................... 79

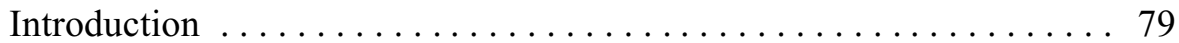

I. The Historical Context of the International Criminal Court $\ldots . .83$

A. The Transformation of the Traditional Nation State into the Global Market State . . . . . . . . . . . . . . . . . . 83

B. The ICC and the United States as Market State . . . . . . . 85

C. The Inevitable Flow of Events $\ldots \ldots \ldots \ldots \ldots \ldots \ldots$

1. The Birth of International Criminal Law . . . . . . . . 87

2. Nuremberg ..................... 91

3. The Creation of the International Criminal Court ...... 93

D. How Should the United States React to the Inevitable Flow of Events? . . . . . . . . . . . . . . . . . 97

II. A Review of Significant International Criminal Cases of the Past Ten

Years ............................ 100

A. The $A d H o c$ Tribunals . . . . . . . . . . . . . . . . . 100

B. Saddam Hussein and the Iraqi Special Tribunal . . . . . . . 103

C. Augusto Pinochet ....................... 106

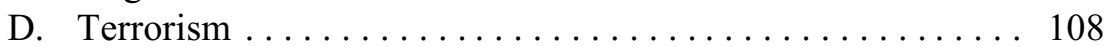

III. Current ICC Procedures, U.S. Objections, and Potential Solutions

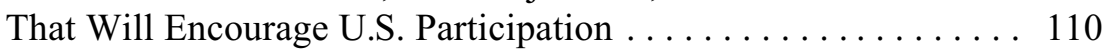

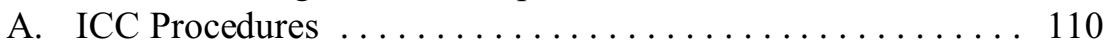

B. U.S. Objections $\ldots \ldots \ldots \ldots \ldots \ldots \ldots \ldots \ldots \ldots \ldots \ldots \ldots \ldots \ldots \ldots \ldots \ldots$

* Visiting Professor, University of Texas School of Law, U.S. Law and National Security, J.D. University of Texas School of Law 1977. The following article reflects the opinions of the author and does not necessarily reflect the position of any U.S. government department or agency. The author would like to thank Professor Roger S. Clark, Rutgers University School of Law, Cambridge, a key member of the ICC preparatory commissions, for his review of this article and invaluable assistance. 
C. Solutions $\ldots \ldots \ldots \ldots \ldots \ldots \ldots \ldots \ldots \ldots \ldots \ldots \ldots \ldots \ldots$

1. Education of Congress and the Public to Correct Misperceptions ................... 118

2. Modifications of U.S. Statutes and ICC Procedures . . . 119

3. Amendments ..................... 121

a. Terrorism ..................... 123

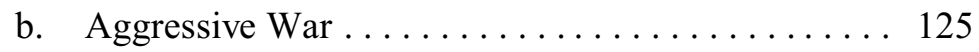

Conclusion ............................. 129 


\section{SYNOPSIS}

The events of the last 150 years have resulted in the foundation of international criminal law, the establishment of an International Criminal Court (hereinafter the "ICC"), and the adoption of an International Code of Criminal Offenses. The author argues that conservatives and nationalists should support the creation of the ICC, in part because the United States (hereinafter the "U.S.") is transforming from a traditional, independent nation state into a global market state, and an enhanced system of international justice can advance our national goals. He further urges that the U.S. should lead, shape, and eventually use the ICC to its foreign policy advantage. By summarizing a number of recent international cases pursued without the benefit of a permanent international court, he elaborates on the problems the cases have encountered due to the nature of the courts handling them. The author then details the U.S.'s public objections to the ICC and responds by explaining why many of these charges do not have merit and suggesting possible solutions. Finally, he outlines how the U.S. can utilize the ICC to combat terrorism and aggressive war in addition to war crimes, crimes against humanity and genocide.

\section{INTRODUCTION}

In examining the response of the U.S. to the development of international law and institutions, one observes that the proponents of an international approach are traditionally idealists and those representing the left wing of American politics. ${ }^{1}$ The opposition tends to be led by conservatives and nationalists. ${ }^{2}$ A review of public statements surrounding the creation of the ICC reveals that it is no exception. The Court was formed, in the words of Kofi Annan, to help "ensure that no ruler, no State, no junta and no army anywhere can abuse human rights with impunity ... that those who violate those rights will be punished." ${ }^{3}$ Organizations such as Human Rights First, ${ }^{4}$

1. One immediately thinks of Woodrow Wilson and the League of Nations, Adlai Stevenson and his early advocacy of test ban treaties, and more frequent utilization of the U.N. See OsCAR THEODORE Barck, Jr. \& Nelson Manfred Blake, Since 1900, A History of the United States in Our Times 188-92, 635, 641-42 (Macmillan Publishing 5th ed. 1974).

2. Republican conservative Senators Henry Cabot Lodge and William Borah led the successful attack on the League of Nations in the U.S. Senate. Id. at 258-63.

3. Press Release, U.N., Kofi Annan, International Criminal Court Promises Universal Justice, Secretary Tells International Bar Association, U.N. Doc. SG/SM/6275 (June 12, 1997), available at, 
Human Rights Watch, ${ }^{5}$ Amnesty International ${ }^{6}$ and Citizens for Global Solutions ${ }^{7}$ have heavily promoted the ICC, and many international lawyers have expressed a "romantic attachment" to the idea that the Court can efficiently judge and deter war criminals and those who abuse human rights. ${ }^{8}$ However, as early as 1998, members of America's political right wing, such as Senators Jessee Helms and John Ashcroft, have made it clear that they viewed the ICC as a threat to U.S. national sovereignty and our preeminence in world affairs." Senator Ashcroft stated that the Court was a "continuing threat to the national interest," 10 while Senator Helms declared that "the United States will never - and I repeat, never - allow its national security decisions to be judged by any international criminal court." 11 Ambassador John Bolton and the Cato Institute ${ }^{12}$ also took strong and early stands against the Court, with Ambassador Bolton declaring that the adoption of the ICC breaches "the American citadel . . ., advocates of binding international law will be well on the way toward ultimate elimination of the "nation state.",13

In light of this ideological contest, it was understandable that Democratic candidate John Kerry stated in the 2004 Presidential Debates that he occasionally supported preemptive war, but that "when you do it ... you have to do it in a way that passes the test, that passes the global test where ... you

http://www.un.org/News/Press/docs/1997/19970612.sgsm6257.html.

4. See Fiona McKay, U.S. Unilateral and International Crimes: The International Criminal Court and Terrorism, 26 CORNELL INT'L L.J. 455 (2004).

5. Human Rights Watch, The United States and the International Criminal Court, http://hrw.org/ campaigns/ice/us.htm (last visited Apr. 27, 2006).

6. International Criminal Court, Amnesty International's Human Rights Concerns, http://www .amnestyusa.org/icc/index.do (last visited Apr. 27, 2006).

7. USA for the International Criminal Court, http://usaforicc.org (last visited Apr. 27 2006) (website funded by Citizens for Global Solutions).

8. See Steven Ratner, Welcoming Remarks, in International War Crimes Trials: Making a DifFERENCE? 12 (Steven R. Ratner \& James L. Bischoff eds., University of Texas School of Law 2004); see also Helen Robertson, Looking Forward: Prospects for the International Criminal Court, id. at 147-53.

9. See Is a U.N. International Criminal Court in the U.S. National Interest? Before the Subcomm. on International Operations of the S. Comm. On Foreign Relations, 105th Cong. passim (1998).

10. Id. at 8 .

11. Id. at 6 .

12. See Gary Dempsey, Reasonable Doubt: The Case against the Proposed International Criminal Court, Cato Policy Analysis No. 311, July 16, 1998, http://www.cato.org/pub_display.php?pub_id=1170.

13. John R. Bolton, The Risks and Weaknesses of the International Criminal Court from America's Perspective, 41 VA J. INT'L L. 186, 193 (2000). Bolton went on to advocate "no financial support . . . no cooperation; and no further negotiations." Id. at 202. 
can prove to the world that you did it for legitimate reasons." ${ }^{14}$ George Bush promptly replied:

I'm not exactly sure what you mean, "passes the global test," ... Let me tell you one thing I didn't sign, and I think it shows the difference of our opinion . . . And that is, I wouldn't join the International Criminal Court. It's a body based in The Hague where unaccountable judges and prosecutors can pull our troops or diplomats up for trial . . My opponent is for ... the International Criminal Court. ${ }^{15}$

President Bush has been true to his word. On May 6, 2002, then Undersecretary of State John Bolton advised the United Nations (hereinafter "U.N.") that "in connection with the Rome Statute of the International Criminal Court ... the United States does not intend to become a party to the treaty ... The United States requests that its intention not to become a party ... be reflected in the depositary's status list relating to this treaty." 16 In the minds of some, the U.S. has gone beyond simply refusing to consider becoming a party to the treaty, to the point that it is aggressively seeking to undermine the Court's existence. Critics state that the U.S. has pursued this objective by negotiating bilateral agreements that prohibit the extradition of U.S. citizens from foreign countries for ICC-related offenses, denying economic aid to any country that does not sign the agreements, and demanding Security Council resolutions that U.N. peacekeeping troops be exempt from ICC jurisdiction. ${ }^{17}$

Of course, once battle is joined, even on ideological grounds, the legal community's discussion can quickly digress into a detailed analysis of the potential and theoretical meaning and implications of statutes, phrases, and individual words. The monumental nature and historical significance of the matter can be lost in the infinite ability of our legal minds to immerse ourselves in the smaller pleasures of nuance, contrary interpretation, and technical distinction. As one can expect, legal literature on the ICC debates at length the true meaning of the key statutory concepts of personal jurisdiction, complementarity, admissibility, "willing and able to prosecute,"

14. Commission on Presidential Debates, The First Bush-Kerry Presidential Debate (Sept. 30, 2004), http://debates.org/pages/trans2004a_p.html (last visited May 3, 2006).

15. Id.

16. Press Statement, Richard Boucher, Spokesmen, U.S. Dep't of State, International Criminal Court: Letter to U.N. Secretary General Kofi Annan (May 6, 2002), http://www.state/r/pa/prs/ps/ 2002/9968.htm.

17. See McKay, supra note 4, at 463-68; Jean Galbraith, The Bush Administration's Response to the International Criminal Court, 21 BERKLEY J. INT'L L. 683, 687-91 (2003). 
and Article 98 agreements. ${ }^{18}$ This is both natural and necessary. Yet one cannot help but believe that the ICC also deserves something better and with a far larger scope because, when one steps back and examines the Court, it is clear that it may be a truly major development in the course of human history.

The following article approaches the ICC in a somewhat unique manner. Specifically, it will attempt to place the Court in the historical and cultural context of the nation state, as well as the flow of events of the last 150 years. This article will also argue from a nationalist and conservative standpoint on matters of international relations and national defense that the ICC may be good for America. That is, from the perspective of one who cares about the world and its people, but is not an internationalist and whose primary allegiance is to the U.S. and its people. Section I of this article will include an historical analysis and policy conclusions based on that review. The following section summarizes the difficulties encountered in a number of high profile international legal cases from the last decade that have proceeded without the assistance of an international criminal court. The final section takes a hard look at reasons for the U.S.'s opposition to the Court, both stated and unstated, and concludes with what the author argues are real and practical answers.

The author, like others before him, will have to wrestle with the meaning of ICC terminology at some point; however, that will not be the primary focus of this article. As will be demonstrated when the author discusses the issues of defining terrorism and aggressive war, as well as the inclusion of those offenses as ICC crimes, the legal community should rise above an obsession with words that can inhibit progress. Only then can it arrive at constructive, meaningful, and positive solutions. Finally, it must be noted that in a few short years, a new administration, whether Republican or Democrat, will initiate and complete a fresh examination of the ICC. Hopefully, this article will help provide a new vision for those who assume that important task.

18. E.g., David J. Scheffer, Staying the Course with the International Criminal Court, 35 CoRNELL INT'L L.J. 47 (2002); M.Tia Johnson, The American Servicemember's Protection Act: Protecting Whom?, 43 VA. J. INT'L L. 405 (2003). These are the two most comprehensive of the many articles on the ICC that discuss these concepts and are cited throughout the course of this article. 


\section{The Historical Context of the International Criminal Court}

\section{A. The Transformation of the Traditional Nation State into the Global Market State}

Perhaps the best place to find a truly large scale historical perspective from which to examine America's approach to the ICC is Professor Philip Bobbitt's recent and highly regarded treatise, The Shield of Achilles: War, Peace, and the Course of History. ${ }^{19}$ While reading this extensively researched book and the scholarly works it cites, one cannot help but wonder whether the traditional, well-defined nation state that some have been staunchly defending by refusing to join the ICC continues to exist.

Everyone knows the basic course of human history up to this point. As Winston Churchill poetically wrote of human evolution in his novel Savrola:

\footnotetext{
When the human race was emerging from the darkness of its origins . . there was only the motive power which we call the "will to live." Then perhaps it was a minor peculiarity of some of these early ancestors of man to combine in twos and threes for their mutual protection. The first alliance was made; the combination prospered where isolated individuals failed ... Gradually, the little societies became larger ones. From families to tribes, and from tribes to nations the species advanced, always finding that the better they combined, the better they succeeded. ${ }^{20}$
}

The result was the development of the self-contained nation state at the end of the Fourteenth century. The primary goals of the nation state have been to provide security for its inhabitants, support its economic welfare, and protect its cultural integrity. ${ }^{21}$

Unfortunately, a direct byproduct of the creation of the nation state has been a series of increasingly horrific epochal wars such as the Hundred Years Wars, the Hapsburg wars, the Thirty Years war, the colonial wars, and the wars of the French Revolution. These culminated in what Bobbitt calls the Long War of 1914-1990 between states supporting fascism, communism, and parliamentarianism. ${ }^{22}$ During this period, strategic innovations such as nuclear weapons and rapid multinational communication emerged that, according to Bobbitt, made it almost impossible for the traditional nation state

19. Philip Bobbitt, The Shield of Achilles: War, Peace, and the Course of History (2002).

20. Winston S. Churc hill, SAVrola 84-85 (Random House, 1956).

21. Воввіт, supra note 19 , at 214-28.

22. Id. at $\mathrm{xxi}, 215$. 
"to fulfill its responsibilities [on its own]. That will account for its delegitimization." ${ }^{23}$

To the relief of nationalists, Professor Bobbit does not go so far as to suggest or advocate the complete elimination of the state as others, such as Jean-Marie Guéhenno ${ }^{24}$ or Kenichi Ohmae ${ }^{25}$ have suggested. What he does envision, however, is the transformation of the traditional territorial nation state into the global "market state." ${ }^{26}$ He defines the global market state as an entity that "depends on the international capital markets and, to a lesser degree . . . on the multinational business network to create stability in the world economy, in preference to management by national or transnational political bodies." ${ }^{27}$ "[T] he market state is culturally accessible to all societies" and "indifferent to race and ethnicity and gender; its yardstick for evaluation is the quantifiable." ${ }^{28}$

Of course works such as Bobbitt's tend to be abstract and theoretical, but upon examining the world landscape, it is hard to proclaim they do not reflect the developing reality. The proliferation of nuclear weapons and chemical and biological weapons of mass destruction make it impossible for one nation to guarantee continuous security and protection for its people by itself. The need and desire to maintain a cultural identity is rapidly decreasing in light of the tremendous mix of cultures one sees everyday on our streets and around the world, all facilitated by efficient transportation and the slow but constant elimination of racial and ethnic barriers. The concept of the national welfare state is being replaced, as evidenced by the statements of Bill Clinton, George Bush and Tony Blair, with the idea that the government should not foster dependence but provide economic opportunity. ${ }^{29}$

At the same time, when traveling outside the U.S., one quickly recognizes the tremendous multinational structure of what were once local or nationwide businesses. McDonald's, Coca-Cola, Marriott, Dell, IBM, General Motors, and other corporations exist and thrive everywhere from the U.S. to Russia, China, and the United Arab Emirates. ${ }^{30}$ These businesses almost form a

23. Id. at 215 .

24. Jean-Marie Guéhenno, The End of the Nation-State (Victoria Elliot trans., University of Minnesota Press, 1995).

25. KenichiOhmae, The End of the Nation State: The Rise of Regional Economies (1995).

26. Boвbitт, supra note 19.

27. Id. at 229 .

28. Id. at 229-30.

29. See id. at $339-41$

30. The author has travelled throughout Western Europe as well as to Qatar and Kosovo and observed the active presence of these multinationals in every nation. 
virtual market state of their own that has no boundaries. Perhaps it only follows that al Qaeda, the enemy that now confronts the world, is not confined to any nation's boundaries, but is itself a true multinational terror network. Whether nation states politically recognize it or not, the world, on its own, is fast becoming one entity.

\section{B. The ICC and the United States as Market State}

In light of this particularly grand overview of world history, how best should those who still primarily believe in the well being of the people of the U.S., whom they may even represent in government, respond to the creation of an International Criminal Court? There are some very good reasons to distrust international institutions, as will be discussed later, and Bobbitt himself does not support many of them as they currently exist, ${ }^{31}$ but the purpose behind the Court certainly appears to complement the needs of the evolving market state. That is, the Court is designed to more effectively deal with and deter genocide, crimes against humanity, war crimes and, eventually, terrorism and aggressive war. Local conflicts, and the above list of internationally recognized crimes and atrocities, do not occur in a vacuum, but quickly spill over into other nations with devastating personal and economic consequences, even for those who live far outside the location of the initial outrage. These crimes create situations requiring nations such as the U.S. to engage in costly military interventions, peacekeeping, and nation building. This happened in Yugoslavia, Iraq, and elsewhere. Prevention through establishment of a firm rule of law is far less economically expensive than the cure for such offenses. ${ }^{32}$ If the ultimate goal of our nation state as it transforms into a market state is to further the health and economic prosperity of our own people, it follows, unless we wish primarily to be an arms supplier, that stability of a kind that might be enhanced by the court through prosecution and deterrence is highly desirable. In addition, citizen travel and business investment increase in times of peace, and consumer demand and markets can greatly expand. American markets may spread all over the globe, but the profits can return home to American citizens.

Deterrence is not necessarily an illusion. As President Clinton stated before he left office, "I believe . . . a properly constituted and structured International Criminal Court would make a profound contribution in deterring

31. See, e.g., Воввітт, supra note 19 , at $341,475,476$.

32. See supra note 8, at 147 (remarks of Helen Robertson at the U.T. Conference) 
egregious human rights abuses worldwide...."33 Professor Douglas Cassell has written that "an effective ICC could contribute to justice, deterrence, diplomacy, global norms and ultimately, to a more humane world." ${ }^{34}$ Professor John Norton Moore and others have noted that abuses take place when "regime elites," usually within non-democratic governments that are not controlled by the people, engage in aggressive behavior with the knowledge that there is no "system wide deterrence." 35 Leaders can externalize the costs of their high-risk behavior by placing it on their own people and neighbors and internalize the potential benefits because there is no one to hold them accountable. Thus, Adolph Hitler, Saddam Hussein, and other dictators had nothing to restrain the domestic and foreign actions they took to maintain or expand power. There was always the possibility that they could flee safely, as the Kaiser did after World War I, if their regimes collapsed and there was no codified body of international law that could confront them. Moore believes that international law and international trials against regime elites can thus be one of the first lines of defense against future human rights abuses, war crimes, and the worldwide disruption that follows these crimes. ${ }^{36}$

The fact that we are evolving into a market state also seriously undermines those who criticize the Court on the grounds that it somehow undermines America's independence and sovereignty. ${ }^{37}$ The truth is that this sovereignty, to the extent the term implies autonomy, disappeared long ago with the global market and international agreements. As Hans Correll wrote:

Those obsessed with saving America's sovereignty from the clutches of international institutions are missing the fundamental point about the new world. America's sovereignty is being lost. To some degree it is lost (at the creation) of the UN and other international bodies. But to a far greater degree American sovereignty is being lost to the forces of globalization. They can insist that America act alone or not at all. But many of the threats we face today, such as ... international crime ... [and] terrorism cannot be defeated single-handedly or shut out at the border. Turning our backs will not turn back the clock. It will only leave us more vulnerable. ${ }^{38}$

33. Statement of the President: Signature of the International Criminal Court Treaty, at $\mathrm{http} / / / \mathrm{clin} t o n 4 . n a r a . g o v /$ textonly/library/hot-releases/December_31_2000.html (Dec. 31, 2000).

34. Douglas Cassell, The Rome Treaty for the International Criminal Court, A Flawed but Essential First Step, 6 Brown J. World AfF. 41, 44 (1999).

35. John Norton Moore, Enhanced Effectiveness in United Nations Peacekeeping, Collective Security and War Avoidance: Toward a New Paradigm, 37 VA. J. INT'L L. 811, 840-41 (1997).

36. Johnson, supra note 18, at 419-24 (citing John Norton Moore, Beyond the Democratic Peace: Solving the War Puzzle (2002) (unpublished manuscript on file with author)).

37. See Dempsey, supra note 12.

38. Hans Correl, The Visible College of International Law: "Towards the Rule of Law in International Relations, ” 95 ASIL Proc. 214, 267, (2001) (citing Anthony LaKe, Six Nightmares 283 
The Webster's Dictionary definition of sovereignty includes "potent," "paramount," "dominant," and "supreme" as synonyms. ${ }^{39}$ It is this sovereignty, from a nationalist's standpoint, that we can and should realistically hope to maintain and enhance in the future. This will not be accomplished by abandoning or trying to subvert an international criminal court designed to help manage an increasingly connected global system. Rather, it can be achieved, as will be discussed in the following section, by leading, shaping, and utilizing the institution to attain America's domestic and foreign policy objectives.

Analyzing the Court at this point, simply from the historical perspective of the U.S. as an emerging global market state along with the demise of the traditional nation state, it would appear that the U.S.'s opposition may not be sound policy.

\section{The Inevitable Flow of Events}

Things in life will not always run smoothly. Sometimes we will be rising towards the heights-then all will seem to reverse itself and start downward. The great fact to remember is that the trend of civilization itself is forever upward; that a line drawn through the middle of the peaks and valleys of the centuries always has an upward trend.

Endicott Peabody ${ }^{40}$

\section{The Birth of International Criminal Law}

There are approximately 20,000 years of recorded history. ${ }^{41}$ Any survey of the past centuries discloses the origin, expansion, and inevitable incorporation into human society of significant and far-reaching innovations. These advances may be technical, moral, governmental, or unfold in any field of human endeavor. For the lawyer contemplating this vast scope of human history, however, one development that should quickly capture his interest is

\footnotetext{
(2000)).

39. Webster's Seventh New Collegiate Dictionary 836 (1965).

40. Jon Meacham, Franklin and Winston 17 (2003) (Endicott Peabody was one of Franklin Roosevelt's instructors at Groton. The quote was spoken in his 1945 inaugural address.).

41. Recorded history in the sense that the very informative cave drawings of southern Europe trace to approximately 16,000 B.C. George E. Stuart, Enigmas from the Past, in Mysteries of the AnCiEnt WORLD 7 (National Geographic Society, 1979). The first writing appeared to be recorded on cuneiform tablets in Sumaria about 3000 B.C., Jared Diamond, Guns, Germs and Steel 218 (1997).
} 
the birth and rapid growth in merely the last one hundred and fifty years of the concept of international criminal law and justice.

One may argue that the basic principles have long been with us, and there is some truth to that. When Senator William Fullbright persistently maintained in a discussion with Justice Jackson before the Nuremberg trials that there was no law on which to try Nazi war criminals, Senator Brian McMahon responded, "I am satisfied to rest on the Ten Commandments." ${ }^{42}$ A provision of the Old Testament actually specifically and in detail forbids the destruction of fruit-bearing trees in enemy territory during war. ${ }^{43}$ The ancient code of Manu, a legendary legislator of India, ordered that "an enemy must not be harmed if he is asleep or naked, or turning to flight or defenseless, or folding his hands for mercy." ${ }^{44}$ The first war crimes trial in history, in terms of punishment for violation of a law of war through judicial process, may have been that of William Wallace of Braveheart fame in 1305 for waging a war of extermination against the English people, "sparing neither age nor sex, monk nor nun. ${ }^{~} 45$ The philosophers of the Age of Enlightenment advocated in their writings that there must be just and humane treatment of prisoners of war because men were only "accidentally" enemies. The real war was between States that these individuals were called upon to serve or defend. ${ }^{46}$

The international law movement, however, appears to have actually begun when lawyers, motivated by the devastation of the Crimean and U.S. Civil Wars, first started to codify enforceable rules of conduct to regulate armies. In 1863, Professor Francis Lieber of Columbia Law School, a veteran of Blucher's famous 1815 Prussian army, wrote at the direction of the U.S. Army what became officially promulgated as the "Instructions for the Government of Armies of the United States in the Field." "T7 This code dealt with the rights of prisoners, non-combatants, and partisans and prohibited the use of poisons or unnecessary violence and destruction. ${ }^{48}$ It was soon followed by the Geneva Conventions of 1864 and 1899, each designed to ameliorate the

42. John Q. Barrett, From Justice Jackson to Thomas Dodd to Nuremberg, address before the Supreme Court Historical Society (Feb. 15, 2005), at http://www.roberthjackson.org/documents/ RHJOoddtTexttoSCHS.pdf.

43. John Fried, War Crimes, available at www.grolier.com/wwii/wwii_warcrime.html (last visited Mar. 20, 2006) (citing Deuteronomy 20:19).

44. $I d$.

45. Id.

46. See Telford Taylor, Anatomy of the Nuremberg Trials 7 (1992) (quoting Jean-Jacques Rousseau); see also Fried, supra note 43.

47. TAYLOR, supra note 46 , at 8-9.

48. Id. at 9 . 
conditions of the wounded. ${ }^{49}$ Perhaps the landmark international breakthrough came at the Hague in 1899 with the signing by twenty-four nations of the "Convention with Respect to the Laws and Customs of War on Land." This document "leaned heavily" on the Lieber code established in the U.S., but also added provisions prohibiting a declaration of no quarter or attacking troops in the act of surrender. ${ }^{50}$ Because this agreement and the Geneva Conventions on treatment of the wounded had been signed by so many separate foreign powers, they became law recognized by the community of nations. Today this is known as international law. Accordingly, they created crimes that

can be punished not only by the organs of the country of which the offender is a citizen - for example a guard who tortures ... but also by the enemy .... Since the rules are "international law," such enemy suspects may be tried and . . . punished even by a nation which has not passed any legislation for such procedures. ${ }^{51}$

German conduct in World War I was widely perceived, in some cases with justification, as outrageous. The result was a demand by the victors after the war for some form of war crimes trials to punish offenses against the now established laws of war. The matter was assigned to a commission whose report, after negotiation among the allies, led to the inclusion in the Versailles Treaty of provisions stating that the Kaiser was to be tried before a special tribunal on charges of an offense "against international morality and the sanctity of treaties," while there would be additional military trials against those who had "committed acts in violation of the laws and customs of war." 52 Interestingly, the commission also found that Germany had launched a "war of aggression," but that, as "this conduct did not provide the basis for a criminal charge under existing international law, it should be strongly condemned and made a penal offense for the future. ${ }^{.53}$

In the end, the high hopes of the allies for the enforcement of a developing international law against Kaiser Wilhelm and Germany were not fulfilled. The Kaiser fled to the Netherlands, and that country refused to extradite him on the rather sensible grounds that a general charge against international morality and the sanctity of treaties really had no sound basis in

\footnotetext{
49. Fried, supra note 43.

50. TAYLOR, supra note 46 , at 10.

51. Fried, supra note 43 (italics omitted).

52. TAYLOR, supra note 46, at 16 (quoting Treaty of Versailles, art. 227, June 28, 1919, 2 Bevans

53. Id. at 15 .
} 43). 
any existing law and appeared more political than criminal. ${ }^{54}$ The allies presented a long list to Germany of individuals who were to be tried on more legitimate charges, such as denying quarter, killing prisoners, and firing on lifeboats, but the German population was indignant and defiant, and their government refused to hand them over. This resulted in a post-war crisis that was only averted when the allies agreed to a proposal that the German Supreme Court try the suspects in Leipzig. ${ }^{55}$ The record of these trials was dismal. "Of the 901 persons . . . incriminated by evidence furnished by the Allies, 888 were either acquitted or not indicted ... The 13 who were found guilty received insignificant sentences [and] were celebrated inside and outside the court as national heroes." ${ }^{56}$ A symbol of these tribunals was the infamous case involving Lieutenants Dithmar and Boldt, who were convicted of destroying two lifeboats escaping from a torpedoed hospital ship, sentenced to four years in prison, then disappeared, apparently with assistance from their German jailers. $^{57}$

Hard lessons were thus learned in the aftermath of the war, but legal precedent was also established. The Allies accepted and, at least initially, attempted to enforce the principles established by The Hague and Geneva conventions. The nations of the world were put on notice that efforts would be made to hold them accountable for war crimes. In addition, the British pushed for and succeeded in obtaining the conviction of at least a few Turkish officials for the massacre of Armenians during the war. ${ }^{58}$ "The word 'genocide' had not been coined, but that is what the Armenian massacres were." $" 59$ There was initial discussion in treaties immediately following the war of offenses related to murder, deportation, and atrocities against civilians separate from direct military action that laid the basis for what eventually became crimes against humanity. ${ }^{60}$ Aggressive war had been identified and singled out for potential future criminal action. The League of Nations, our first attempt at a true world body of states, had been created and along with it a multinational Permanent Court of International Justice designed to solve international disputes. ${ }^{61}$ Finally, in 1937, the failure to convict German war

\section{Id. at 16.}

55. Id. at $17-18$

56. Fried, supra note 43.

57. See Ronald J. Sievert, Cases and Materials on U.S. law and National Security 199-204 (2000).

58. TAYLOR, supra note 46, at 18.

59. Id.

60. Johnson, supra note 18 , at 416 .

61. Id. 
criminals after World War I, along with the need to protect human rights, led to the very first drafts at Geneva of a Convention on the Creation of an International Criminal Court. ${ }^{62}$

\section{Nuremberg}

Before the community of nations could approve a functioning international criminal court, they were enmeshed in the worldwide catastrophe of World War II brought on by Germany's invasion of its neighbors and outrageous treatment of domestic and foreign populations. "Nazism was a proudly avowed repudiation of the libertarian, humanitarian, and internationalist ideals to which most national governments gave at least lip service" in the decades before the war. ${ }^{63}$ As evidence of German atrocities piled upon the record of blatant aggression, a clamor arose among the Allies for the prosecution of individuals and leaders for war crimes when the war ended. This led to the 1943 establishment of a Commission for Investigation of War Crimes. ${ }^{64}$ The big three, Churchill, Roosevelt, and Stalin, did not, however, immediately sign on to the idea of trials for either leaders or their subordinates. At Tehran in November 1943, Stalin proposed, perhaps in jest, that 50,000 Germans should be rounded up and summarily shot. Churchill responded indignantly that the British public would not tolerate mass executions. To relieve the tension between them, Roosevelt then "offered a compromise-only forty-nine thousand German officers would be shot." Finally, at Yalta, they agreed on drawing up of a list of war criminals to be tried in accordance with later established law and judicial procedures. The process should not, however, according to Roosevelt, "be 'too judicial' and journalists and photographers should be kept out 'until the criminals were [executed]."

Roosevelt selected Justice Robert Jackson to lead the American effort during the war crimes trials, and President Truman later appointed him to the position of Chief Counsel. ${ }^{67} \mathrm{He}$ subsequently negotiated the London Charter, which set forth the procedural and substantive groundwork for the anticipated war crimes trials. It included as potential charges against individual

62. Id. at 416 n.50.

63. TAYLOR, supra note 46 , at 21.

64. Id. at 26; Fried supra note 43.

65. MeAcham, supra note 40, at 260.

66. Martin Gilbert, Churchill 821 (Henry Holt and Co. 1992) (1991).

67. TAYLOR, supra note 46 , at 39 . 
defendants Aggressive War (Crimes Against Peace), War Crimes, and Crimes Against Humanity. ${ }^{68}$ All of these terms, of course, traced back to Versailles.

As a result of the earlier treaties and post-World War I prosecutions, war crimes or violations of the laws and customs of war had already emerged as recognized violations of international law. This was not the case with aggressive war or crimes against humanity, which, although discussed, had not yet been accepted by the community of nations. Nevertheless, Jackson had stated as early as 1941 that "aggressive wars are civil wars against the international community." He accused the Axis powers of shamefully violating the Kellogg-Briand Pact of 1928, which "condemn[ed] recourse to war" and "renounce[d] it as an instrument of national policy," but did not specifically make war a criminal offense. ${ }^{69}$ He now felt that unjustified aggressive war was the most serious crime, the one that encompassed and foreshadowed all the others. ${ }^{70}$ At the end of the trial, the Nuremberg Tribunal agreed, holding that aggressive war was the "supreme international crime," and the renunciation of war in the Kellogg-Briand Pact "involves the proposition that such a war is illegal." 71 Aggressors should lose their rights as lawful belligerents and their acts of war are crimes. ${ }^{72}$

Crimes against humanity included murder, extermination, deportation, and torture committed against civilian populations, as well as attacks based solely on religious or ethnic grounds. ${ }^{73}$ Persecution based on ethnicity was now, for the first time in court, called "genocide." 74 The French prosecutor justified trying these crimes against humanity on the basis that they were violations "of the laws of all civilized countries which have been committed by Germany in the conduct of the war." 75 The Tribunal agreed that the German actions would constitute violations of the law of nations, but linked

68. Agreement For the Prosecution and Punishment of the Major War Criminals of the European Axis, Charter of the Military Tribunal, art. VI, Aug. 8 1945, 59 Stat. 1544, 82 U.N.T.S. 279 [hereinafter London Charter].

69. TAYLOR, supra note 46 , at 37,44 .

70. Id. at 54-55.

71. Fried, supra note 43.

72. This comes from Col. Robert Chanler's early theory on aggressive war which helped formed the basis of the prosecution. See TAYLOR, supra note 46, at 37 (detailing Chanler's thinking and the decisions to accept his basic idea).

73. London Charter, supra note 68 , art. VI(c).

74. See TAYLOR, supra note 46, at 103 (noting that term was coined by Raphael Lemkin of the

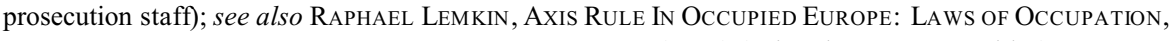
Analysis of Government, Proposals for Redress 79 (1944) (using the term "genocide").

75. TAYLOR, supra note 46, at 293-94. 
them to the war and war crimes in such a way that it is arguable one must commit them as part of a war. ${ }^{76}$

The overall effect of Nuremberg on the developing field of international law was enormous. Nuremberg "initially implanted the criminality of initiating aggressive war as an accepted rule of international law." 77 It also was "the watershed event for enforcement of international humanitarian and human rights violations." abstract, were identified as being responsible for the commission of these newly established crimes. ${ }^{79}$ Approximately 161 of these individual defendants were eventually convicted and sentenced in the German trials, and another twenty-five in similarly constituted tribunals in the Far East. ${ }^{80}$ The 1946 resolution of the U.N. General Assembly "affirm[ing] the principles of international law recognized by the Charter of the Nuremberg Tribunal and the judgment of the Tribunal" further enhanced the authority of this new law and endorsed the judgments. ${ }^{81}$ Thus, through a series of trials of responsible individuals, punishments, and U.N. ratification, enforceable international criminal law was firmly established.

\section{The Creation of the International Criminal Court}

The newly created U.N. quickly returned to the idea of an international criminal court to try war crimes and crimes against humanity. ${ }^{82}$ By the late 1940 's, however, the politicization of virtually every U.N. enterprise generated by the increasing enmity of the Cold War had prevented these efforts from achieving any real results. ${ }^{83}$ No significant progress was made until the conflict began to dissipate in the Reagan-Bush-Gorbechev era. As Ambassador David Scheffler observed:

With the end of the Cold War and the growing number of democracies and pluralistic societies committed to the advancement of human rights and the rule of law, it simply is

77. TAYLOR, supra note 46, at 635 .

78. Johnson, supra note 18 , at 416 .

79. International Military Tribunal (Nuremberg), Judgments and Sentences, 41 Am. J. INT'LL. 172, 221 (1947).

80. Fried, supra note 43.

81. G.A. Res. 95(1), at 188, U.N. Doc. A/64/Add.1 (Dec. 11, 1946).

82. See Johnson, supra note 18 , at 417.

83. Id. See also Justice Richard Goldstone, The Trial of Saddam Hussein: What Type of Court Should Prosecute Saddam Hussein and Others for Human Rights Abuses, 27 FordHAm InT'L L.J. 1490, 1494 (2004). 
no longer tenable either among democratically elected political leaders or among the public they serve to tolerate impunity for the commission of [crimes against humanity and war crimes]. The victims of [such] international crimes voice a much stronger determination to see that justice is rendered. Civil society has mobilized to support victims, investigate international crimes, and pressure governments and international organizations to react effectively. Where the will exists within the international community, there is enormous pressure to find the means to fulfill that political and societal resolve in favor of justice..$^{84}$

The U.S. Congress was onboard with the concept of the ICC early, and its resolutions did not always envision that this institution would be confined to traditional war crimes. In 1986, Congress stated that " $[\mathrm{t}]$ he President should also consider including on the agenda for [international] negotiations the possibility of eventually establishing an international tribunal for prosecuting terrorists." ${ }^{95}$ In 1988, Congress expressed that the President should "begin discussions with foreign governments to investigate the feasibility and advisability of establishing an international criminal court to expedite cases regarding the prosecution of persons accused of . . . international drug trafficking or having committed international crimes." ${ }^{966} \mathrm{In}$ 1994, the 103rd Congress included a provision in the Foreign Relations Authorization Act to the effect that,

The establishment of an international criminal court with jurisdiction over crimes of an international character would greatly strengthen the international rule of law ... [and as] such a court would thereby serve the interests of the United States and the world community ... the United States delegation should make every effort to advance this proposal at the United Nations" $" 87$

President Clinton followed suit in 1995 in a speech at the University of Connecticut, advocating that "nations all around the world who value freedom and tolerance [should] establish a permanent international court to prosecute ... serious violations of humanitarian law." ${ }^{98}$

The U.N. responded fairly expeditiously to create the Court once international pressure and U.S. support became manifest. In 1989, the U.N. International Law Commission was asked to draft the charter for an

84. Scheffer, supra note 18 , at 51.

85. Omnibus Diplomatic Security and Antiterrorism Act of 1986, Pub. L. No. 99-399, § 1201(d), 100 Stat. 853, 896 (1986).

86. Anti-Drug Abuse Act of 1988, Pub. L. No. 100-690, § 4108(a), 102 Stat. 4181, 4267 (1988).

87. Foreign Relations Authorization Act, Fiscal Years 1994 and 1995, Pub. L. No.103-236, $\S 517($ b), 108 Stat. 382, 469 (1994).

88. William J. Clinton, Remarks at the University of Connecticut in Storrs, 2 PUB. PAPERs 1597 (Oct. 15, 1995). 
international criminal court. ${ }^{89}$ Before the Court could be established, the U.N. Security Council had to authorize ad hoc tribunals in 1993 and 1994 to deal with the crises in Yugoslavia (International Criminal Tribunal for the Former Yugoslavia) and Rwanda (International Criminal Tribunal for Rwanda), respectively. ${ }^{90}$ These formulated their own procedures and had to rely on precedents and general covenants to determine the current status of enforceable customary war crimes and humanitarian law. ${ }^{91}$ By 1995, however, the Preparatory Committee on the ICC had been established to begin the hard work of drafting procedural and substantive law for a permanent court. The U.S. dispatched Ambassador David Scheffer to represent our interests at committee meetings with the instruction that he help fashion a document that could be useful in the prosecution of members of rogue states while essentially guaranteeing that U.S. servicemen and high level officials would never be prosecuted. ${ }^{92}$ He had a tremendous influence on the negotiation process and from a practical standpoint, as will be discussed later, almost completely satisfied the difficult mandate he had been given. By July 17, 1998, the Rome Statute detailing the rules and procedures of the International Criminal Court had been adopted. ${ }^{93}$ The Statute was then submitted by the U.N. to the nations of the world with the understanding that upon ratification by sixty states, it would enter into force and the Court would begin operation.

Opposition, however, had arisen on the right in the U.S. Congress. Senator Helms felt the Rome Statute was "irreparably flawed" because, in his opinion, it was potentially applicable to citizens of non-parties, could lead to second guessing of U.S. foreign policy decisions, diluted the Security Council's powers, and created an independent prosecutor accountable to no government or institution. ${ }^{94}$ Regardless of the merit of these criticisms, which will be analyzed in section III, concern about the possible politically motivated

89. G.A. Res. 44/39, ๆ 1, U.N. Doc. A/RES/44/39 (Dec. 4, 1989).

90. Goldstone, supra note 83 , at 1495 .

91. The tribunals relied upon Nuremberg, the 1949 Geneva Convention, the 1948 Universal Declaration of Human Rights, the 1976 International Covenant on Civil and Political Rights, and other agreements and precedent to come to an understanding of customary law related to war crimes, crimes against humanity, and genocide which would form the basis for the criminal charges against the defendants. See, e.g., Prosecutor v. Furundiga, Case No. IT-95-17/1 -A, Judgement (July 21, 2000); Prosecutor v. Tadic, Case No. IT-94-1-A, Judgement (July 15, 1999); Geoffrey Robertson, Crimes Against Humanity: The Struggle for Global Justice 285-323 (New Press 2000) (1999).

92. Scheffer, supra note 18 , at $47,57$.

93. Rome Statute of the International Criminal Court, July 1, 2002, 2187 U.N.T.S. 90 [hereinafter Rome Statute].

94. See Senate Hearing on the ICC, supra note 9, at 6 (statement of Sen. Jesse Helms, Member, S. Subcomm. on International Relations). 
prosecution of U.S. officials by the Court enabled Helms to secure passage of the American Servicemembers' Protection Act. ${ }^{95}$ It prohibited U.S. cooperation with the Court, including the use of taxpayer funding, demanded that the U.N. exempt future U.S. peacekeepers from the ICC, prohibited financial aid to nations which did not promise they would not extradite U.S. citizens to the Court, and authorized the President to take military action to rescue soldiers handed over to the Court, sometimes referred to as the Hague Invasion Act. ${ }^{96}$ President Clinton, reacting to the conservative criticism, signed the treaty on December 31,2000, but stated he would not recommend submission of the document for ratification until any necessary corrections had been incorporated. ${ }^{97}$ The Bush administration subsequently "unsigned" the Treaty by indicating its intent not to become a party in 2001 .

The Rome Treaty, however, showed no signs of being hindered by U.S. opposition. It was ratified by the necessary sixty nations and went into force on July 1, 2002. The ICC's Assembly of State Parties elected the first eighteen judges in February 2003 and the Chief Prosecutor on April 23, 2003. As of September 1, 2005, it had been ratified by 99 countries including England, France, and Canada, leaving the U.S. allied with such opposing nations as Vietnam and North Korea. ${ }^{98}$ In perhaps the most significant event in international criminal law since Nuremberg, the Assembly of State Parties met on September 10, 2002 and adopted a major codification of international crimes and their elements. ${ }^{99}$ These included five crimes of Genocide, sixteen Crimes against Humanity and seventy-one War Crimes. ${ }^{100}$ Furthermore, the

95. See generally American Servicemembers' Protection Act of 2002, Pub. L. No. 107-206, 116 Stat. 899 (codified at 22 U.S.C. §§ 7401, 7421-7433 (Supp. III 2003)).

96. $\S \S 2004-2008,116$ Stat. at $902-06$.

97. See Statement on the Rome Treaty on the International Criminal Court, 3 Pub. PAPERs 2816 (Dec. 31, 2000).

98. See World Signatures and Ratifications, Coalition for the International Criminal Court, http://www.iccnow.org/?mod=romesignatures\&PHPSESSID=a3059fa7b19c68b6c1ce4a8263613754 (last visited Apr. 5, 2006) (listing country signature and ratification dates of the Rome Statute).

99. See Assembly of State Parties to the Rome Statute of the International Criminal Court [ASPICC], First Session, New York, 3-10 September 2002: Official Records, U.N. Doc. ICC-ASP/1/3 (Sept. 10, 2002) [hereinafter ICC-ASP: First Session]. During the special tribunals, the Judges would have to determine the elements of the crime in each case based on customary law. The elements were never known until the judgment was rendered AND approved by the Appeals Court. See Daryl A. Mundis, Knut Dörman, with Contributions by Louise Doswald-Beck and Robert Kalb, Elements of War Crimes Under the Rome Statute of the International Criminal Court, Sources and Commentary, 2 J. InT'L CRIM. JuST. 929, 929-30 (2004) (book review). See also Roger S. Clark, The Mental Element in International Criminal Laws: The Rome Statute of the International Criminal Court and the Elements of Offences, 12 CRIM. L.F. 291 (2001) (discussing the highly difficult task of assigning mental states to the ICC offenses).

100. ICC-ASP: First Session, supra note 99, at 108-55. 
ICC announced that a Preparatory Commission, a Review Conference, and the Assembly of State Parties would meet in the years ahead to consider adding in seven years, if definitions can be agreed upon, the crimes of terrorism and aggressive war to the list of international law violations over which the Court has jurisdiction. ${ }^{101}$

\section{How Should the United States React to the Inevitable Flow of Events?}

In the short span of 150 years, international criminal law has thus expanded from the first principles announced in Lieber's Civil War military rules of governance to the adoption of an established, globally-recognized, and formal international criminal code backed by a permanent international court that almost all of the world's civilized nations have approved. When one views this development from the perspective of thousands of years of recorded history, words such as avalanche, eruption, on rushing tide, phenomena, and inevitable come to mind. Nuremberg, the ad hoc ICTY and ICTR, the ICC, and now the adoption of substantive criminal law are all pillars upon which an enforceable body of law has been built. International criminal law now exists just as torts, contracts, property, and admiralty law. ${ }^{102}$ How, then, should an individual who believes foremost in the strength of the U.S. and the welfare of its people react to this International Criminal Court? In the author's opinion, the answer is by re-establishing leadership, shaping the Court, and proceeding to use it to the U.S.'s advantage.

When the Senate rejected Woodrow Wilson's League of Nations, he commented that, "[t]hey will have to learn now by bitter experience just what they have lost .... We had a chance to gain the leadership of the world. We have lost it, and soon we shall be witnessing the tragedy of it all." ${ }^{103}$ His

101. Rome Statute, supra note 93, art. V, $\uparrow 2$ (stating that the court shall exercise jurisdiction over the crime of aggression once a provision is adopted in accordance with articles 121 and 123); Art. CXXI, CXXIII (dealing with amendments which may not be made until seven years after the entry into force of the statute); United Nations Diplomatic Conference of Plenipotentiaries on the Establishment of an International Court, Rome, Italy, June 15-July 17, 1998, Final Act of the United Nations Diplomatic Conference of Plenipotentiaries on the Establishment of an International Criminal Court, res. E-F, U.N. Doc. A/CONF. 183/10* (July 17, 1998) [hereinafter Diplomatic Conference of Plenipotentiaries, Final Act] (stating that the Review Conference would consider adding terrorism and narcotics offenses to the list of ICC crimes and the Preparatory Commission would prepare proposals for a provision on aggression). See also McKay, supra note 4, at 456-57 (regarding discussions on the inclusion of terrorism).

102. In fact, International Criminal Law Casebooks have now been published. See, e.g. Edward M. Wise et al., International Criminal Law: Cases and Materials (2d ed. 2004); Kriangsak KitTichaisaree, InTER NATIONAL CRIMINAL LAW (2001).

103. BARCK \& BlAKE, supra note 1 , at 192. 
belief in the eventual need for international institutions led by the U.S. was actually shared at the time by Republican Theodore Roosevelt. Roosevelt, Wilson's constant nemesis and as realistic a nationalist as Wilson was an idealist, said that if the idea of an international police force was utopian, then we must choose between "Utopia or Hell." 104 Franklin Roosevelt followed Wilson, announcing the creation of a U.N. and proclaiming that there must be "an end to unilateral action, exclusive alliances and spheres of influence" that have always failed. He proposed to substitute a "universal organization in which all peace loving nations will finally have a chance to join." 105 There was no question who he thought should lead it. In his words:

The power which this nation has attained-the political, the economic, the military, and above all the moral power-has brought to us the responsibility, and with it the opportunity, for leadership in the community of nations. In our own best interests, in the name of peace and humanity, this nation can not, must not, and will not shirk that responsibility. ${ }^{106}$

Despite America's critics, the U.S. has generally lived up to Roosevelt's promise of leadership towards peace and humanitarian reform through sponsorship of treaties and covenants, and even providing a large part of the financial support for the U.N. ${ }^{107}$ As James Rubin said, the U.S. has long been viewed as "the leading force for the rule of law and the leading force... in the fight against war crimes and crimes against humanity."108 Our withdrawal from the Rome Treaty creating the ICC, therefore, is "a remarkable reversal of American international law enforcement policy sustained throughout the 20th century" placing the U.S. for the first time in the position of an "enemy of the rule of law." 109

This policy has serious and potentially negative consequences for the U.S. First, by abandoning participation in ICC meetings such as the Preparatory

104. Id. at 244. Theodore Roosevelt had first publicly advocated an international police force when he accepted the Nobel Prize in 1910. Roger Beaumont, Right Backed by Might: The International Air ForCe CONCEPT 8 (2001). Henry Cabot Lodge had also at one point favored a united community of nations before he set out to destroy Wilson's League. BARCK \& BLAKE, supra note 1, at 244 .

105. Mедснам, supra note 40, at 321 (Franklin Roosevelt speaking before Congress on Mar. 1, 1945).

106. Id. at 307-08 (Franklin Roosevelt speaking in New York, New York, October 22, 1944).

107. The United States is the largest single contributor, providing approximately 25 percent of the U.N. budget. See William Reilly, U.S. Regains Seat on UN Budget Committee, UPI, Nov. 5, 1999, http://news.excite.com/news/u/9911005/22/international-arrears-un.

108. James P. R'ubin, U.S. Department of State, Daily Press Briefing, July 20, 1998, http://www.hri.org/news/usa/std/1998/98-07-20.std.html.

109. Scheffer, supra note 18 , at 53-54. 
Commission conferences on procedures, evidence, elements of crimes, and new offenses, the U.S. loses its ability to mold the ICC in a way that will make it more efficient as well as protective of U.S. interests. ${ }^{110}$ As a consequence, our options to "actively influence" the development of the organization are greatly limited. ${ }^{111}$ Second, although there has always been only a slim possibility that U.S. officials and soldiers would be prosecuted while we were a major player (see section III), the fact is that the attitude of prosecutors and judges at the ICC towards potential U.S. defendants will naturally change as the U.S. becomes an active opponent. ${ }^{112}$ It is just not the same situation as it would be were the U.S. on the line with them fighting the world's evil-doers and, just incidentally, supplying a good portion of the budget funding the Court's operation. Finally, standing in opposition to 99 nations unified in support of the rule of law, the U.S. comes across as a self-centered unilateralist at the exact time we are trying to build a coalition of nations against worldwide terrorism. ${ }^{113}$ As Ambassador Scheffer writes, "[t]he long war against terrorism will be incompatible with any American effort to oppose and dismantle the ICC. If only in its own self interest, the United States will want to collaborate with its allies and friends around the world." ${ }^{114}$

By rejoining the Court and reassuming the leadership role the U.S. had before Undersecretary Bolton "unsigned" the treaty, America would not only avoid the negative consequences outlined above, but also shape the Court in a manner that would allow the U.S. to use it in the future. In the first section of this article, the author noted that dictators who commit atrocities and initiate wars that draw in the major powers at great personal and financial cost often can only be deterred when there are specifically known, adverse consequences that will be directly imposed on them as a result of their actions. Punishment by the ICC can be such a deterrent that would clearly benefit the U.S. and its allies. ${ }^{115}$ This deterrence can be further enhanced by the Court's eventually incorporating aggressive war into the list of prosecutable international crimes. The author noted earlier that the ICC is working on this concept. In Section III, this article will discuss elements and parameters that many nations may accept in trying to define that crime. It is enough to say at

110. Id. at 59.

111. Galbraith, supra note 17 , at 699 .

112. Scheffer, supra note 18 , at 58.

113. Johnson, supra note 18 , at 470.

114. Scheffer, supra note 18 , at $49-50$.

115. See Clinton, supra note 88; Cassell, supra note 34 , at 44 . See also Goldstone, supra note 83 , at 1502-03. Although I do not believe the U.S. needs an ICC to be deterred, the Judge may be correct in believing that its presence had an effect on U.S. planners. 
this point that it would certainly be to the U.S.'s advantage if it could clearly put the leaders of China, North Korea, Iran, and other nations on notice that there is a real possibility that an unjustified invasion of their neighbors could eventually result in their being placed in the dock before the world.

The U.S. could also utilize the Court as a tool in the war against terror. The theoretical worldwide war against terrorists too often looks like a battle between the U.S., Great Britain, and Israel on one side and the terrorists on the other. Virtually all civilized nations believe that those who commit terrorist acts should be identified, captured, and punished. The ICC could be the vehicle that visibly engages the world in pursuing that goal. Prosecutor Louis Ocampo has noted that he would be willing to prosecute al Qaeda for the World Trade Center attacks based solely on the crimes against humanity charges currently available in the ICC criminal code. ${ }^{116}$ The ICC will also meet to define the crime of terrorism per se as a prosecutable offense, and Section III of this article discusses a potentially acceptable definition. ${ }^{117}$ The key is that the U.S. needs, as Ambassador Scheffer has written, to "explore the utility of the ICC as a potent judicial weapon in the war against terrorism." 118

\section{A Review of Significant International Criminal Cases of the Past Ten Years}

It is very helpful in evaluating the need for an effective international criminal court guided and strengthened by the U.S. to review the progress of several major international criminal cases that have arisen or been tried in the last decade without the assistance of a permanent court. Although domestic and international systems have had some success in handling such cases, the record is not impressive.

\section{A. The Ad Hoc Tribunals}

The Security Council deserves credit for authorizing the creation of the ad hoc international tribunals for Yugoslavia and Rwanda and the hybrid local-international courts in Sierra Leone and East Timor. They stand for the

116. James Podgers, An Unused Weapon: International Criminal Court Could Play Role in War Against Terrorism, Says New Chief Prosecutor, ABA JournaL, Sept. 19, 2003, http://www.globalpolicy .org/intljustice/icc/2003/0922 iccterror.htm (reporting on O'Campo's remarks during an ABA meeting).

117. See Mckay, supra note 4; Diplomatic Conference of Plenipotentiaries, Final Act, supra note 101, res. E.

118. Scheffer, supra note 18 , at 50. 
principle that "[t]he rule of law can lead to a cultural shift where we move from impunity to accountability." "119 "[T] hey have proved that international courts can put on fair trials ... [and] put an end [by means of courtroom evidence] to the false denials that accompanied the commission of war crimes." 120 But these courts have been plagued with problems that stem from their lack of permanence. Neither the ICTY nor ICTR appeared to have effective procedures for protecting civilians who came before the court before and after their testimony. There are numerous reported incidents of disturbing treatment of both victims and witnesses and indications that the overall system sometimes subjected them to ridicule, humiliation, intimidation, or other forms of mistreatment. ${ }^{121}$ In East Timor, the tribunals did not live up to expectations because of "a lack of investigative continuity, a lack of resources and poor management, a lack of out reach and accessibility [to the community], and a lack of cooperation from Indonesia[, the home of the primary suspects]."122 In Rwanda, the trials were so slow and apparently unconnected to the population that the government increasing turned to "gacaca," as trial by local community elders is known. This indigenous remedy has been in turn subject to withering criticism from "international human rights lawyers and international lawyers for not fully replicating the standards set out by the international criminal trial model." ${ }^{23}$ Publicity and communication about the ICTR in Rwanda was so bad that "a vast majority of respondents [surveyed] claimed that they knew virtually nothing about the ICTR." "24 The majority of those interviewed in Serbia knew "a little" or "very little" about the ICTY, and only 10 percent had any confidence that trials would be impartial. ${ }^{125}$

When problems are discovered in these temporary tribunals, they are not corrected expeditiously because the U.N. is "very clumsy and unwieldy ....

119. Robertson, supra note 8, at 148.

120. Goldstone, supra note 83, at 1499-1500.

121. See Kelly Askin, International Criminal Tribunals and Victim-Witnesses, in InTERnATIONAL War Crimes Trials: Making a Difference 49, 51-56 (Univ. of Tex. Law Sch. 2004).

122. See Nehal Bhuta, Remarks of Nehal Bhuta, in InTERnAtional WAR Crimes Trials: Making A Difference 121, 125 (Univ. of Tex. Law Sch. 2004).

123. Timothy Longman, Question and Answer Session, in International War Crimes Trials: Making a Difference 41, 44 (Univ. of Tex. Law Sch. 2004); Mark Drumbl, Question and Answer Session, in International War Crimes Trials: Making a Difference 41, 45 (Univ. of Tex. Law Sch. 2004).

124. Timothy Longman, The Domestic Impact of the International Criminal Tribunal for Rwanda, in International War Crimes Trials: Making a Difference 33, 37 (Univ. of Tex. Law Sch. 2004).

125. Igor Bandovic, Remarks of Igor Bandovic, in InTERnATIONAL WAR CRIMES TRIALS: MAKING A Difference 90, 95-96 (Univ. of Tex. Law Sch. 2004). 
Once you have a bad combination or a bad situation within a unit or an institution, it's unusual that this is quickly able to be corrected, and it takes some time before the right mix of resources and people are brought together in a way that makes that institution effective." 126

Reflecting on the litany of complaints, Helen Robertson, the head of Canada's efforts to support the ICC, has stated:

These ad hoc tribunals were a welcome step, but not a permanent solution. To keep creating such tribunals leads to delays, primarily because they are established after the fact. It is costly and inefficient to create a new institution for each situation, and can also lead to allegations of selective justice. A permanent institution can overcome these defects. It will be ready, up and running, have investigators, and have expertise; and by its permanent presence it will be a more effective deterrent. ${ }^{127}$

Addressing some of the major difficulties encountered by the temporary tribunals, Sam Muller, Deputy Director of Services for the ICC, noted that a permanent court will have the resources to establish structures and systems to allow the Prosecutor, the Judiciary, and the Registry to retrieve, assess, and utilize large quantities of detailed information. This goes to the core of the Court's relationship with those on the ground and will increase accessibility to those around the world. He further emphasized that the ICC will not neglect victims and witnesses, stating that "[v]ictim participation, protection, and compensation are an innovative aspect of the Rome Statute and consume a significant amount of the resources of the Court. This is the case as victims are the individuals who have the greatest stake in the cases that the Court will face." $" 128$

The above factors all strongly suggest that the ad hoc tribunals are not a sound alternative to the ICC. As a practical matter, it is unlikely that the U.N. would create any more such tribunals at the request of the U.S. Ambassador Scheffler has noted that U.S. advocacy of ad hoc tribunals would suffer because of our continued opposition to the more popular ICC. "As a non signatory, U.S. credibility to pursue ad hoc initiatives would rapidly decline." ${ }^{129}$ Moreover, because the "collective effort in creating the ICC was enormous .... [it] may now prove difficult to generate international support

126. Bhuta, supra note 122 , at 125-26.

127. Robertson, supra note 8 , at 148 .

128. Sam Muller, Establishing an Effective International Criminal Court, in INTER NATIONAL WAR Crimes Trials: Making a Difference 132, 132 (Univ. of Tex. Law Sch. 2004).

129. Scheffer, supra note 18 , at 59 . 
for the international prosecution of war criminals via other means." ${ }^{\text {"130 }}$ ICC party nations may simply not want to put funds and energy into establishing a separate tribunal.

\section{B. Saddam Hussein and the Iraq Special Tribunal}

Another major criminal case with international implications that has been proceeding without the assistance of an international criminal court is the investigation and trial by the Iraqi Special Tribunal of Saddam Hussein and his associates. The Iraqi offenses could not have been tried by the ICC because the ICC does not have jurisdiction over events that took place before its creation, but the problems that are associated with this tribunal, as is the case with the ad hoc tribunals and the other offenses to be discussed in this section, illustrate why the world needs a strong international criminal court.

In 2002, the U.S.-led Coalition Provisional Authority and the fledgling Iraqi Governing Council agreed to proposals that Saddam Hussein and his collaborators be tried by Iraqi Judges and prosecutors in Iraq as opposed to seeking international assistance and a potential trial at the Hague. The authorities consulted international and Iraqi legal experts and drafted a statute for the tribunal that incorporates international procedural law established at the ad hoc tribunals, the substantive code of war crimes, crimes against humanity and genocide adopted by the ICC, and Iraqi law. ${ }^{131}$ The first major challenge is that, although international law can be immensely complicated, the prosecutors and judges who will try these cases have no international experience. As stated by Mark Ellis, Executive Director of the International Bar Association, in a discussion of the Iraqi judiciary, "[t]hese judges, although very qualified judges, none of them have had any experience dealing with crimes of genocide, crimes against humanity, war crimes, and this substantive area of law is complicated in and of itself." "132 At the same time,

130. Galbraith, supra note 17, at 692-93.

131. See Iraqi Special Tribunal: Questions and Answers, Human Rights First, http://www .humanrightsfirst.org/international_justice/w_context/w_cont_10.htm. See also Iraqi Special Tribunal, http://www.iraq-ist.org (last visited Mar. 28, 2006) (providing, inter alia, the Statute of the Iraqi Special Tribunal and a discussion of the law and cases). Those who know the author may also know that he has some experience in this area. For a number of reasons, however, this section is confined to what has been written by others in published reports and not based on personal observations.

132. Morning Edition (National Public Radio broadcast Aug. 4, 2005) (remarks of Mark Ellis, Executive Director, International Bar Association). Human Rights Watch also repeatedly makes the same complaint. See, e.g., Saddam Hussein as P.O.W., Human Rights WAtch, Jan. 22, 2004, http:/hrw.org/ english/docs/2004/01/27/iraq7076.htm. 
some in the government occasionally threaten or pressure the judges because they are former members of the Baath Party, even though they could not have gained any legal experience as judges if they had not joined the party under Saddam Hussein. ${ }^{133}$

The statute for the Iraqi Special Tribunal provides that international judges may assist, but to date the international legal community has not joined in the process because the statute does not exclude capital punishment. ${ }^{134}$ Many international lawyers, for solid reasons of principle, believe that the death penalty violates basic human rights and that it should be abolished as a form of punishment. The Iraqis, for equally good reasons involving the circumstances of these particular cases, refuse to abandon it.

There are a number of additional problems with the IST. Some defendants and their attorneys have complained about lack of access to attorneys. ${ }^{135}$ As possible evidence of this type of "misstep" by the IST, the IBA's Ellis noted that "when Saddam was first brought before the court . . . [h] a appeared without any representation, and, in fact, he was allowed to express his thoughts and opinions that - an attorney would never have permitted that to occur." "136 Human Rights groups have also highlighted that the IST statute does not require that a defendant's guilt be proven beyond a reasonable doubt as is customary both in common law nations and cases before international tribunals. ${ }^{137}$

A further concern with the IST is that the trials are being held in Iraq. Venue is a difficult issue. There is and should be a definite preference to hold trials in the local geographical area if possible. As Justice Goldstone has stated, "[t]here can be no question that criminal trials should ideally be held where the crimes were committed. It is very important for courts, especially criminal courts, to be accessible to the victims, so that the victims can feel part

133. See Morning Edition (National Public Radio broadcast Aug. 4, 2005) (remarks of Judith Yaphe, Senior Fellow, National Defense University).

134. See The Trial of Saddam Hussein: Q-and-A, Human Rights Watch, Nov. 24, 2004, http://hrw .org/english/docs/2004/11/24/iraq9725.htm. Human Rights Watch is not assisting despite pulling together much of the early evidence of the Anfal assault on the Kurds in part because it believes the death penalty is "unique in its cruelty and invariably carried out in an arbitrary manner." See also Goldstone, supra note 83, at 1496 (noting "[t]here was no way the European powers would have agreed to the death penalty" in an international court for Rwanda despite the desires of the Rwandans).

135. See William Langewiesche, Ziad for the Defense, The Atlantic Monthly, June 2005, at 68, 70,72 .

136. See Morning Edition (National Public Radio broadcast Aug. 4, 2005) (remarks of Mark Ellis, Executive Director, International Bar Association).

137. The Trial of Saddam Hussein: Q-and-A, supra note 134. 
of the process." 138 One of the reasons that Rwandans felt that victims were treated poorly and that the nation was unconnected, as noted above, was that the trials were held in Arusha, Tanzania instead of Kilgali, Rwanda. As Goldstone further emphasizes, however, sometimes it is just not possible to hold the trials locally. "There is no way in 1993 or 1994 that the [ICTY] could have sat in Sarajevo or Zagreb or Belgrade" or for the ICTR to meet in Kigali because of ethnic tensions and lack of security. ${ }^{139}$ In his opinion:

[g]iven the situation in Iraq at the moment, to put on a trial in Baghdad today is just beyond any thought. How can you have a trial with bombs going off daily, people being attacked daily? How can you expect a court to sit in Baghdad and be able to operate and have a fair trial? ${ }^{140}$

Finally, in reviewing the press releases of the Iraqi Special tribunal, although Saddam Hussein and those who assisted him are being investigated for the numerous internal crimes related to the genocide against the Kurds, atrocities and unjustified executions in al Dujayl, and mass killings of Shites in the south, there has been no mention of the filing of charges of aggressive war related to the invasion of Kuwait. ${ }^{141}$ This is true even though the IST statute specifically authorizes the invocation of the 1958 Iraqi statute prohibiting use of armed force against an Arab state. ${ }^{142}$ It was the unilateral invasion of Kuwait which led to the first Gulf War, the sanctions, the second Gulf War, and the occupation and the current insurgency against the legitimate government of Iraq. Again, in Justice Jackson's opinion, aggressive war is the most serious crime, the one that encompasses and foreshadows all others. ${ }^{143}$ Perhaps because the invasion of Kuwait is an external matter involving a foreign complainant, it has not been a priority for the Iraqi tribunal. Although the internal atrocities committed by Saddam Hussein's regime are horrendous, one would expect that the invasion of Kuwait would have been a primary focus of a true international court concerned with international justice.

138. Goldstone, supra note 83, at 1497.

139. Id. at 1496-97.

140. Id. at 1505 .

141. See Iraqi Special Tribunal, http://www.iraq-ist.org/en/press/releases.htm (last visited Mar. 28, 2006). The list of press of press releases regarding actions and defendant interviews does not refer to any charges filed against Hussein or members of his regime related to the invasion of Kuwait. The only case legally referred to the Iraqi Special Tribunal as of March 28,2006 is the al Dujayl case, although the Anfal case relating to genocide against the Kurds apparently is under active investigation. Id.

142. Statute of the Iraqi Special Tribunal, art. 14, § c (2003), available at http://www.cpairaq.org/human_rights/Statute.htm.

143. See TAYLOR, supra note 46 , at 54-55. 
The lack of international experience on the part of the Iraqi judiciary, the political pressure the court must face, the questions surrounding the tribunal's procedures, the difficulty of holding trials in Baghdad, and the tribunal's neglect of the Kuwaiti invasion all, individually and in combination, reflect serious problems that must be overcome by the Iraqi government. Future cases in other nations will encounter exactly the same challenges if they are handled by a local court. A permanent international court, however, can avoid virtually all of these problems.

\section{Augusto Pinochet}

The strange events surrounding the recent attempted prosecution of Augusto Pinochet, the former dictator of Chile, further illustrate the need for a strong and effective ICC. Pinochet led the coup that overthrew democratically elected Chilean President Salvador Allende. ${ }^{144}$ After he had left office, a civilian commission reported that secret police had assassinated or "disappeared" 3,197 people under his rule. Tens of thousands were tortured and more forced into exile. ${ }^{145}$ Some of these individuals were Spanish citizens. Pinochet also apparently ordered the murder of former Allende defense minister Orlando Letelier and his associate Ronni Moffit by car bomb in Washington, D.C. in $1976 .{ }^{146}$ When he relinquished the presidency following his election loss, Pinochet was named a Senator for life and granted himself amnesty for any crimes he may have committed. ${ }^{147}$

In 1998, Spanish Magistrate Baltasar Garzón charged Pinochet with genocide, terrorism, and torture for his crimes committed against both Spanish citizens and Chilean citizens under the principle of universal jurisdiction and issued a warrant for his arrest. ${ }^{148}$ Pinochet was arrested in England on October 16, 1998. There were three hearings on the case before panels of the English House of Lords in the next two years. After the first hearing, Lords held that Pincohet was not entitled to immunity for his actions as a former head of state and he could be extradited. In the second case, the Appeals Committee of Lords decided to vacate the first order because of alleged bias

144. Stacie Jonas, The Ripple Effect of the Pinochet Case, Human Rights Brief, Spring 2004, at 36.

145. Saul Landau, Indictment a Victory for International Law, Miami Herald, Dec. 30, 2004, available at $\mathrm{http}: / /$ www.tni.org/archives/landau/victory.htm.

146. $I d$.

147. $I d$.

148. Jonas, supra note 144, at 36. 
by one of the initial judges. Finally, after a third hearing, a reconstituted panel of Lords held that Pinochet was not completely immune from prosecution and that he could be extradited. ${ }^{149}$ At that point, British Home Secretary Jack Straw claimed that medical doctors had declared Pinochet unfit to stand trial and he had to be returned to Chile instead of extradited to Spain. ${ }^{150}$

Pinochet returned to Chile in 2000, but the Chilean Congress granted immunity to all "former Presidents of the Republic." 151 In 2002, Chilean Judge Juan Guzman asked the national courts to strip Pinochet of his parliamentary immunity. They did so, and Pinochet was arrested in Chile. Guzman's attempt to prosecute Pinochet, however, has been stymied by court ordered suspensions of the case on medical grounds. ${ }^{152}$

This chain of events raises numerous questions. The primary inquiry, of course, is where and by whom should someone like Pinochet be tried when he has committed large-scale human rights violations against his own citizens and Spaniards, as well as an assassination by bombing in Washington. Is this a Chilean, Spanish, or American case, or possibly an English case because he was arrested in England, and defendants who commit crimes against humanity may be tried anywhere under universal jurisdiction? Should the English foreign minister, or even a series of panels of doctors each representing completely different courts, decide whether the defendant is medically eligible for trial? Does England, or any nation, have the right on its own to decide that act of state or sovereign immunity does not apply to the defendant? Can Chile protect the defendant by the simple expedient of granting full immunity to all former Presidents of the Republic on its own?

Commentators have severely criticized the actions taken by the nations involved in the Pinochet case. In his article "Sovereign Immunity Under International Law: The Case of Pinochet," Jonathan Black-Branch stated that the English House of Lords could not independently undercut the longstanding doctrine of sovereign immunity. That must be done by the U.N. or international tribunals so that one sees it as the collective will of the international community. Individual states should not become the "human rights police of the world." 153 Ben Chigara, in his essay "Pinochet and the

149. LyonetteLouis-Jacques, Book Review, 29 InT'L J.LEGAL InFo. 161, 162 (2001) (reviewing THE Pinochet Case: A Legal and Constitutional Anal ysis (2002)).

150. Anup Shah, The Pinochet Case, Sept. 18, 2001, http://www.globalissues.org/Geopolitics/ icc/pinochet.asp.

151. Jonas, supra note 144 , at 36 .

152. $I d$.

153. Louis-Jacques, supra note 149, at 164. 
Administration of International Criminal Justice," arrives at the same conclusion, stating that, "international crimes are best dealt with by international tribunals rather than national courts," as this affirms the "international will to deny offenders the opportunity to hide behind state immunity and state sovereignty for individual acts inconsistent with appropriate state behavior." 154

An effective international criminal court would solve the many problems raised by any situation similar to the Pinochet case. One set of highly qualified doctors reporting to one court could determine medical status. Extradition would be handled under settled procedures established for all ICC defendants. The issue of sovereign immunity would be considered, and probably completely rejected or at least discarded for acts that are not consistent with the duties of a head of state, ${ }^{155}$ by one court representing the international community. There would be no competing pronouncements or competing prosecutions, but, hopefully, an orderly process designed to insure the efficient administration of justice.

\section{Terrorism}

Terrorist attacks against one nation should ideally be tried in either the civilian or military courts of that nation. ${ }^{156}$ But terrorist groups such as al Qaeda are global and they do not confine their activities to any one nation, as evidenced by their operations in South Asia, Africa, Europe, and the U.S. This pattern of activity raises questions as to whether the best course is always to defer to national prosecution as opposed to some form of international trials.

As previously stated, the global war on terror already looks too much like a battle between the U.S., United Kingdom, and Israel on one hand and fundamentalist Islam on the other. It should, in both appearance and fact, be a confrontation between the civilized world and terrorists. The International Criminal Court is one instrument that can help create this necessary focus. In addition, relying on national trials against a group that attacks in numerous locations and injures those of many different nationalities will naturally lead to competition between nations for the first and most important trials. If, for example, an individual such as Osama Bin Laden or one of his key deputies

154. Id.

155. See Rome Statute, supra 93, art. 27 (Irrelevance of Official Capacity).

156. See generally Ronald Sievert, War on Terrorism or Global Law Enforcement Operation?, 78 Notre DAme L. Rev. 307 (2003) (discussing the best forum for trials involving terrorist acts). 
were arrested, Kenya, Tanzania, the United Kingdom, Spain, Afghanistan, Iraq, and the U.S. would all have claims against them. One cannot assume that all countries would simply defer to the U.S. The actual location of trial might depend on the location and circumstances of the capture.

The cases that have been initiated against members of al Qaeda in the U.S., Germany, and Spain also demonstrate the difficulties in proceeding against a multinational terrorist organization in separate jurisdictions. Specifically, Germany decided to try Mounir al-Motassadek on charges that he was a key member and treasurer of the German terrorist cell that included 9/11 pilots Mohammed Atta and Marwan al-Shehhi. ${ }^{157}$ Their prosecution was greatly hindered, however, by the fact that the U.S. would not deliver material witnesses Khalid Sheik Mohammed or Ramzi bin al-Shibh either in person or through means that would reassure the court they had not been tortured. ${ }^{158}$ Trial observer Andreas Schulz stated that, "[t]he situation is like if you have to fight with one arm tied in the back. They have to see how they can convince the court that the evidence left is enough at least for a minimum conviction." 159 Al-Motassadek was originally convicted for aiding the hijackers, but his case was reversed on appeal because of U.S. refusal to provide additional evidence. He was subsequently convicted and sentenced to seven years in prison on the lesser charge of being a member of a terrorist group. ${ }^{160}$

Meanwhile, Spain and Germany have compromised the U.S.'s ability to prosecute and convict all of those involved in 9/11. Germany not only did not send alleged co-conspirator al-Motassadek to the U.S. for trial, but when the U.S. sought evidence from Germany against suspected conspirator Zaccarias Moussaoui for his U.S. trial, "German authorities ... expressed reluctance to turn over evidence they had about Moussaoui because of concerns regarding his possible execution." 161 At the same time, Spain has twenty-four individuals in custody suspected of helping to use that nation as a staging ground for the 9/11 attacks. One of them, Imad Yarkas, is alleged to have provided logistical cover for the key plotters. Another, Syrian Ghasoub alAbrash Ghalyoun, shot detailed video of the World Trade Center that was

157. See Profile: Mounir al-Motassadek, BBC News, http://news.bbc.co.uk/2/hi/europe/ 2223152.stm.

158. See id.; Interview with Andreas Schulz, PBS Frontline, http://www.pbs.org/wgbh/ pages/frontline/shows/front/map/schulz.html.

159. Interview with Andreas Schulz, supra note 158.

160. See Profile: Mounir al-Motassadek, supra note 157.

161. See Pete Yost, Moussaoui Case May Widen U.S., European Divide, The Press of AtLantic CiTY, Apr. 24, 2005, at A3, available at 2005 WLNR 6450161. 
"passed on to 'operative members of al-Qaeda and would become the preliminary information on the attacks against the twin towers." 162 Despite their suspected complicity, they are not being tried in the U.S. because Spain has said it will not extradite terrorist suspects to the U.S. if they could be executed. ${ }^{163}$

Accordingly, the largest terrorist case in history is spread between three nations, all of which, to one degree or another, are interfering with the other's ability to handle the cases appropriately. It may thus be more efficient to try future terrorist acts before the single forum of an international criminal court. As Louis O'Campo has stated, these offenses may occasionally fit within the elements of various Crimes Against Humanity. It is probably even better, however, as noted in the next section, to define and establish in the code of the ICC an offense of international terrorism.

\section{Current ICC Procedures, U.S. Objections, and Potential Solutions that will Encourage U.S. Participation}

\section{A. ICC Procedures}

When Ambassador David Scheffer joined the international negotiations to establish the ICC, he hoped to create an organization that might prosecute rogue nations but, at the same time, virtually "guaranteed 100 percent protection" for U.S. officials and service members. ${ }^{164}$ He did not quite succeed, but the efforts he and others made to protect their nations resulted in a series of strict procedures that must be followed before any defendant can be indicted and convicted.

The Court only has jurisdiction over "the most serious crimes of concern to the international community": ${ }^{165}$ genocide, crimes against humanity, and war crimes, as defined in the statute and adopted elements of crimes. ${ }^{166}$ Each of these categories of crimes have self-imposed limitations. Thus, genocide requires the "intent to destroy, in whole or in part, a national, ethnic, racial or religious group." 167 A crime against humanity, such as murder, enslavement,

162. Spain Puts 24 al-Qaeda Suspects on Trial, U.S.A. TodAY, Apr. 21, 2005, http://www .usatoday.com/news/world/2005-04-21-spain_x.htm (quoting Spanish Magistrate Baltasar Garzón).

163. See Yost, supra note 161.

164. Scheffer, supra note 18, at 57.

165. See Rome Statute, supra note 93, Preamble.

166. Id. art. 6-8.

167. $I d$. art. 6 . 
or torture, must be "committed as part of a widespread or systematic attack directed against a civilian population, with knowledge of the attack." ${ }^{168}$ War crimes, such as intentionally attacking a civilian population or deprivations against POWs, must be "committed as part of a plan or policy or as part of a large scale commission of such crimes." 169

The prosecutor may proceed with the investigation of a case if he receives a referral from the Security Council under Chapter VII of the U.N. Charter, a referral by a State that is party to the ICC, or on his own motion. ${ }^{170}$ If he is acting on his own or based on a referral from a State party, the crime must have occurred in the territory of a State party or the defendant must be a citizen of a State party. ${ }^{171}$ In addition, if the prosecutor initiates the case, he should notify the States that would normally have jurisdiction, ${ }^{172}$ and he must receive approval of a Pre Trial Chamber that can hear from victims and presumably States that have an interest in the matter. ${ }^{173}$ If the Pre Trial Chamber authorizes the commencement of an investigation, "The State concerned ... may appeal to the Appeals Chamber against a ruling of the Pre Trial Chamber." 174 A prosecutor who successfully clears these hurdles may still have his investigation deferred for twelve months by request of the Security Council, and that request for deferral may consistently be renewed. ${ }^{175}$

An ICC case, therefore, must meet strict subject matter guidelines. In some instances the investigation must be authorized in the early stages by a pre trial chamber and an appeals chamber, and the entire prosecution may be delayed at any time by the Security Council. In addition to these tests, the Rome Statute established a further set of criteria that must be met before the case can be successfully brought to trial. Specifically, the trial Court must consider "issues of admissibility." "176 These include a determination of whether the case is of "sufficient gravity to justify further action by the court." 177 This presumably means a reexamination of whether the crime is one of serious concern to the international community: for example, how

168. Id. art. 7.

169. Id. art. 8.

170. Id. art. 13 .

171. Id. art. 12

172. $I d$. art. 18

173. Id. art. 15 .

174. Id. art. 18 .

175. Id. art. 16

176. $I d$. art. 17

177. $I d$. art 17, § (1)(d). 
widespread and systematic the attacks were or if they were part of a plan or policy. ${ }^{178}$

Admissibility, however, also includes an analysis of "complementarity." Specifically, the Court is designed to complement, not supplant, State systems. Therefore, it will defer to a State and declare a case "inadmissible" for ICC prosecution if a State has already started an investigation, even if the State decides not to proceed "unless the decision resulted from the unwillingness or inability of the State genuinely to prosecute." 179 To determine unwillingness, the court will examine whether there has been an intention to shield defendants, unjustified delays, biased proceedings, or a substantial collapse of a country's judicial system. ${ }^{180}$ Accordingly, to paraphrase former U.N. Undersecretary General for Legal Affairs Hans Correl, unless a State is intent on conducting a sham trial to shield a violator, or there is a breakdown in its ability to carry out judicial proceedings, the ICC should not be a threat to any State with an organized judicial system. ${ }^{181}$

\section{B. U.S. Objections}

There has been a long litany of complaints voiced by conservative commentators to the ICC. ${ }^{182}$ The author has seriously examined these from the view of one who is very sensitive to any possibility of the America's enemies successfully using the ICC as a forum to attack the U.S. on the international stage. Even when examined from this perspective, however, most of the criticism appears to be either ill informed about the basic contents of the Rome Treaty, does not reflect corrections made before its adoption, indicates a lack of knowledge of international procedures long sanctioned by the U.S., or relies on highly unlikely hypotheticals. To the extent that there is any merit to these protests, the author believes that a few adjustments in ICC procedure, as will be proposed later in this section, would go a long way towards correcting any problems.

As one example of such criticism, Gary Dempsey, ${ }^{183}$ Lee Casey, and David Rivkin $^{184}$ state that the ICC would deprive Americans of our well-

178. Johnson, supra note 18 , at 438-39.

179. Rome Statute, supra note 93, art. 17, § (1)(b). § (a) has similar language for cases which are being investigated by the State.

180. Id. art. $17, \S(2)$

181. Correl, supra note 38, at 214, 268.

182. See, e.g., Dempsey, supra note 12; Bolton, supra note 13; Helms \& Ashcroft, supra note 93.

183. Id.

184. Lee A. Casey \& David B. Rivkin, Jr., The International Criminal Court vs. the American 
recognized guarantees of due process as reflected in the Bill of Rights. Specifically, they allege it would deprive citizens of the right against selfincrimination, the right not to be tried twice for the same offense, the right to obtain witnesses, and the right to indictment and trial by jury. Article 55, however, states that a defendant has the right to remain silent and this will not be used against him, ${ }^{185}$ Article 67 states he shall have the right to obtain witnesses on his behalf, ${ }^{186}$ and Articles 17 and 20 are emphatic that, unless there has been an attempt to shield a defendant with a sham trial, no person shall be tried for conduct for which he has been tried in another court. ${ }^{187}$ The complaint that the ICC does not provide a jury trial ignores the fact that U.S. soldiers do not have a right to a Grand Jury indictment and civilian jury trial, ${ }^{188}$ that the U.S. tried the Nuremberg defendants before a tribunal of judges, and that the U.S. promoted trials by judges for the offenses committed in Rwanda and Yugoslavia.

Monroe Leigh, representing the American Bar Association, testified before Congress that, when it comes to due process rights, "the list . . . guaranteed by the Rome Statute is, if anything, somewhat more detailed and comprehensive than those in the Bill of Rights." " Wedgwood has written that "the ICC is carefully structured with procedural protections that carefully follow the guarantees and safeguards of the American Bill of Rights and other liberal constitutional systems ... American negotiators at Rome worked hard to insure that the permanent ICC would follow demanding standards of due process." 190

Some have expressed concern that individual American soldiers will be prosecuted by the ICC. ${ }^{191}$ Ambassador Pierre-Richard Prosper played on this fear by stating in a 2003 speech that, "We currently have service members stationed in over 100 countries at a given time ... and we believe that there are people who would want the opportunity to go after one of our service

People, http://www.heritage.org/Research/InternationalOrganizations/BG1249.cfm.

185. See Rome Statute, supra note 93, art. $55 \S(1)-(2)$.

186. $I d$. art. $67 \S(1)(\mathrm{e})$.

187. Id. art. 17,20 .

188. The Fifth Amendment exempts those in the military. They are tried by military commissions or command selected military juries.

189. Hearing before the House Comm. on Int'l Relations on the International Criminal Court, 106th Cong. 92, 96 (statement of Monroe Leigh).

190. Ruth Wedgwood, The Constitution and the ICC, in the United States and the International Criminal COURT 119, 121 (2000).

191. Dempsey, supra note 12, at 22-24. 
members for political reasons." "192 The ICC, however, is obviously not designed to go after individual servicemen. The crimes over which it has jurisdiction require that they be committed with intent to destroy an entire race, as part of widespread or systematic attack on a civilian population, or as part of a plan or policy to commit war crimes. As Ambassador Scheffer wrote:

The threshold for any ICC investigation and prosecution of crimes is high enough that it is unlikely that the United States and its official personnel would plan and engage in such extraordinary severe and systematic crimes so as to trigger the subject matter jurisdiction of the court. The jurisdiction of the court is limited to 'the most serious crimes of concern to the international community as a whole.' . . . the ICC can not expend its resources on the investigation and prosecution of isolated war crimes by individual soldiers ... the ICC will look foolish pursuing an individual soldier for an isolated war crime that does not meet the important criteria set forth (in the statute.) ${ }^{193}$

There have also been objections that individual U.S. citizens could be extradited to the ICC from foreign countries when they allegedly have a right to be tried in the U.S. or at least under American Rules of Criminal Procedure. ${ }^{194}$ There are, however, no such rights for the citizens of the U.S. or any other country. An American who commits a violation of law in another country can be tried in that country under that nation's law. As Professor Wedgwood points out, "Americans do not have a right to take the Constitution with them into foreign lands as a transnational shield against foreign government action." ${ }^{195}$ Nor are Americans protected if they return to the U.S. after violating the law in a foreign state. In an extradition hearing, "the judge is not entitled to withhold extradition simply because the trial procedures differ in some respects from American trial procedures." 196 Considering the lack of due process protections provided in some nations, the U.S. would probably often want a U.S. citizen arrested on a crime over which the ICC had jurisdiction transferred to an organization like the ICC instead of left to face the consequences in a nation that offered few rights to defendants, and whose judiciary was biased or controlled by the local government.

192. Pierre-Richard Prosper, Justice Without Borders: The International Criminal Court, 17 TemP. INT'L \& CoMP. L.J. 85, 86 (2003).

193. Scheffer, supra note 18 , at 91-92.

194. Dempsey, supra note 12, at 22-24.

195. WeDGWOOD, supra note 190, at 23.

196. Id. at 124 
It is hard to understand exactly what is meant by general Congressional comments that the ICC somehow undermines Security Council power. ${ }^{197}$ The Security Council has not very often demonstrated any real power in world affairs because its rules prevent substantive action if there is a veto by any one of five permanent nations with frequently differing views. ${ }^{198}$ Yet the Rome Statute still defers to the Security Council by allowing it to refer cases for prosecution and to stop any investigation or prosecution for twelve months. This power can be indefinitely extended. Furthermore, as will be discussed below, many nations have taken the position that the ICC will not be able to prosecute any nation or individual for aggressive war without first obtaining a finding by the Security Council that there was an act of aggression.

The final objection stated by the U.S. is that the prosecutor's power is unchecked. In the words of Ambassador Prosper, "the ICC put a system in place that we believe creates a prosecutor who is answerable virtually to no one-a prosecutor who needs only the approval of two of his or her colleagues from the trial chamber before moving forward with a particular process or investigation." 199 This statement seems to ignore the procedural obstacles a prosecutor must overcome before he can try a case and obtain a conviction. As noted above, the Pre Trial Chamber, which is composed of judges, not a prosecutor's "colleagues," must first authorize the prosecutor's decision to investigate. ${ }^{200}$ The rules apparently allow the investigated party to present evidence to the Pre Trial Chamber and to appeal an adverse ruling to another court. If the case survives this process, then the trial court will determine admissibility before it proceeds. ${ }^{201}$ This means another judicial body will evaluate whether the case meets the elements of the crimes in the ICC statutes and whether the case is of sufficient gravity to be presented to the ICC. This court will also reexamine the issue of complementarity with the strong presumption that if a State has already investigated and or prosecuted the case, then the ICC will not do so. In addition, even if a case is still alive after all of this review by different judicial bodies, the Security Council can step in and demand that the investigation be stopped.

197. See Hearing on the United Nations International Criminal Court before the Subcommittee on International Relations of the Senate Committee on Foreign Relations, 105th Cong. 15-16 (1998).

198. See http://www.un.org/Docs/sc/. The Security Council has 10 temporary members and 5 permanent members (U.S., Great Britain, Russia, China and France.) Substantive matters require 9 votes including concurrence of all 5 permanent members.

199. Prosper, supra note 192, at 86.

200. Rome Statute, supra note 93, at art. 15.

201. Rome Statute, supra note 93. 
Of course all of these expressed concerns ignore the practical fact that there are few nations in the world as careful as the U.S. when it comes to attempting to avoid anything that might be categorized as genocide, a war crime, or crime against humanity. In his speech at Fordham in 2004, Justice Goldstone stated:

It is common knowledge that the NATO countries involved (in the bombing of Yugoslavia) had military lawyers sitting with the military commanders, telling them what were and what were not justifiable military targets. Civilian lives were spared.... In the United States bombing in Afghanistan and the Taliban, there was great publicity given to the orders to avoid civilian casualties, and regret expressed when civilians were killed in error . . . . Their intention was to protect civilians. In Iraq . . . every measure within reason was taken not to attack innocent civilians. ${ }^{202}$

Furthermore, there are few countries as aggressive as the U.S. when it comes to prosecuting its own when they cross the line of permissible conduct, as evidenced by the response to the Abu-Ghraib prisoner abuse scandal. After a thorough investigation, the Army convicted all of those who were responsible for knowing and intentional criminal acts at that facility. ${ }^{203}$ Finally, although the author does not believe the war in Iraq is "another Vietnam," in all likelihood, the war will probably have at least one Vietnamstyle legacy. That is, the media coverage and casualties will probably make the nation and its leaders "gun shy" for years, with the result that one should not expect a large-scale aggressive use of military force by the U.S. in the near future. If we do have such a war, there is every reason to believe that the U.S. will continue its policy of making every effort to follow the rules of war.

In light of all these fairly clear answers to the objections of those who have protested against the court, why is there still opposition? Why has the U.S., in the words of one reporter, sacrificed this "huge expenditure of political capital ... to address potential cases which I think most people feel hypothetical in the extreme." ${ }^{204}$

The answer may be more psychological than real. In a deeply philosophical article on U.S. opposition to the ICC, Paul Kahn states that "[o]pposition to the Court has little to do with the substantive threat it

202. Goldstone, supra note 83 , at 1503 .

203. The United States obtained nine convictions. These convictions were of the soldiers who knowingly and intentionally participated in the misconduct. Despite early media and defense-sponsored rumors that the prisoner abuse at Abu-Ghraib was somehow authorized by high officials, the evidence demonstrated that the defendants acted on their own essentially for their own amusement. See T.A. Badger, England Sentenced for Abuse of Inmates, Salt Lake Tribune, Sept. 28, 2005, at A3.

204. Galbraith, supra note 17, at 682 . 
represents to particular American goals and little to do with fear of political misuse ... . The threat to the United States is not practical, it is symbolic." ${ }^{205}$ He further writes:

The conflict over the Court today is so intense not because the practical stakes are high, but because the jurisdiction of the Court has become the site for a symbolic battle between law (ICC)and politics (America). Supporters of the Court tend to believe that twentieth century politics led to the devastating violence of that century ... In this new century the politics of vital national interests should be replaced by the managerial and technocratic sciences of the welfare state on one hand, and a regime of universal law on the other. Both constrict the space that remains open for the traditional politics of nationstates. $^{206}$

In Kahn's opinion, because in America, politics, through popular sovereignty, and law are actually "a single phenomenon constitutive of the national political identity," as opposed to contrasting forces of politics and law, it is difficult to replace them with European sponsored law based on universal reason. ${ }^{207}$ This "would suggest an end to the unique American political project." ${ }^{208}$

Kahn may be correct in his perception of deep-seated American attitudes. His article would explain why many of the U.S. objections to the Court appear so specious. Yet none of this really justifies the U.S. position in light of the negative consequences of its withdrawal from the Treaty and its failure to utilize the court. If some form of chauvinism is at the heart of our opposition, Americans need to understand, as indicated below, that the ICC in its present form really owes as much, if not more, to America than it does to Europe and the international community.

\section{Solutions}

As noted in the previous section, there are few, if any, practical reasons why the U.S. should not become a member of the ICC. Regardless of merit, however, the objections listed have support. What concrete steps, therefore, can be taken to: 1) ease the concerns expressed in these objections, and 2) entice Congress and the next Administration to join the ICC?

205. Paul W. Kahn, Why the United States Is So Opposed, http://www.crimesofwar.org/ icc_magazine/icc-kahn.html.

206. Id.

207. $I d$.

208. $I d$. 


\section{Education of Congress and the Public to Correct Misperceptions}

The first obvious need is to correct the misperceptions in regards to the due process guarantees provided by the ICC, the possibility of individual American soldiers being brought before the Court, and the perceived power of the prosecutor to indict and try the U.S. on his own whim. The real truth behind ICC procedures, as noted above, needs to be clarified for all who have been previously misled.

The second step is to make it clear to Congress and the American people that the ICC is not something foisted on the U.S. by the U.N. and old Europe. In many ways, it is an American creation. As noted in the previous history, the original format for war crimes traces back to Lieber's code for the Union army in the civil war. ${ }^{209}$ It is this code that the first Hague conventions adopted. In 1986, 1988, and 1994, the U.S. Congress passed resolutions strongly supporting the establishment of an international tribunal to try international criminals and terrorists because it was in the best interests of the U.S. and the world community. When it came to drafting the Rome Statute, the U.S. played an extremely active role in the negotiations and was responsible for large sections of it, such as those relating to defendants' rights and complementarity. ${ }^{210}$

It will also be important to insure that Congress and the next administration understand the failings in the major international trials that have been held in the last ten years. One may think we can always ask for another ad hoc tribunal, but, as noted, it is unlikely the U.N. will agree, and the ad hoc tribunals had serious problems with the lack of continuity and resources. At the same time, the Saddam Hussein and Augusto Pinochet cases have exposed the lack of international experience at the national level, the propensity of governments to interfere if they have any control, and the issues of venue when multiple countries have an interest. The al Qaeda trials in the U.S., Germany, and Spain have also disclosed a lack of cooperation between nations that can perhaps only be overcome when there is one prosecuting authority. ${ }^{211}$

209. See supra text accompanying notes $46-47$.

210. Cite to the legislative history/drafting of Rome Statute.

211. See supra text accompanying notes 156-62. 


\section{Modifications of U.S. Statutes and ICC Procedures}

In addition, there are some fairly straightforward modifications to U.S. law and the Rome Statute that can be made to calm American fears. For example, Ambassador Scheffer suggests that domestic law being amended to ensure that ICC crimes can be investigated as complementarity is "the primary and strongest line of defense against unwarranted charges against Americans." ${ }^{212}$ His essential point is that if the listed war crimes, crimes against humanity, and genocide were part of the U.S. criminal code, the ICC could not proceed against the U.S. on the grounds of the "inability" of the U.S. to prosecute. Many of the ICC crimes are probably covered in one form or another by state, federal, or UCMJ statutes prohibiting such offenses as murder, assault, civil rights, and property offenses. Nevertheless, Scheffer's point is well taken; we would not want a case to slip through a gap in U.S. Statutes and thus prevent the domestic prosecution of an offense such as the forcible transfer of a population, using civilian shields and conscripting children as soldiers. Title 18 of the U.S. Code is a hodgepodge of offenses including statutes prohibiting the importation of flying foxes, ${ }^{213}$ and the unauthorized use of the character or name of Smokey the Bear and Woodsy Owl, ${ }^{214}$ along with mail fraud, wire fraud and drug offenses. ${ }^{215}$ It should not be a major problem to add offenses of the serious magnitude of those included in the ICC statutes. However, these crimes contain terms of art and need to be interpreted by those who understand their meaning. Therefore, one should insure that they are not charged by individual District or U.S. Attorneys by requiring that they be utilized only after receiving the approval of the Attorney General. This is standard practice for crimes such as espionage and terrorism. ${ }^{216}$ It would be logical to extend it to war crimes, crimes against humanity, and genocide.

Ambassador Prosper objected on the basis that he believed the prosecutor could bring a case against the U.S. simply by obtaining the consent of two judges on the Pre Trial Chamber. ${ }^{217}$ The ICC process, however, appeared to be much more complicated than this objection indicated. ${ }^{218}$ Regardless, it

212. Scheffer, supra note 18 , at 98 .

213. 18 U.S.C. $\S 42$.

214. Id. $\S 711,711(\mathrm{a})$.

215. 18 U.S.C. $\S \S 1341,1343 ; 21$ U.S.C. $\S 841$.

216. See U.S. Department of Justice, U.S. Attorneys manual, Prior Approvals.

217. Prosper, supra note 192 , at 86.

218. See notes 199-200 and accompanying text. 
might calm U.S. concerns if the ICC would agree to expand the Pre Trial Chamber from three to seven or nine, thereby insuring that more judges agreed before a case was brought against the U.S. An informal agreement could also be made with the ICC to place judges associated with the U.S. or its allies on the Pre Trial Chamber.

There are also modifications that could be made to the Rome Statute that might provide an even greater role for the Security Council than previously suggested. Currently, the Security Council can refer cases for prosecution and defer investigation and prosecution. As with all Security Council actions under Chapter VII of the U.N. Charter, however, one veto by any of the five major nations can prevent action. ${ }^{219}$ It is understandable why the U.N. might want to maintain this arrangement when it comes to authorizing the use of force. Yet for ICC matters, a more flexible approach could be adopted. For example, when it comes to a request for deferral of prosecution, it might be possible to require a vote of only nine of fifteen members without a veto provision. If the U.S. or another nation had a good reason why the case should be postponed, there is a much greater chance they could convince eight other members than get by without a veto by one of its enemies among the permanent five.

The same applies to the principle of aggressive war that will be discussed below. Any prosecution of aggressive war will likely require a finding of aggression by the Security Council, General Assembly, or International Court of Justice. When it comes to the Security Council, it will almost be impossible to insure that not one of the five permanent members vetoes a finding of aggression even if the invasion is carried out by a rogue State without justification. This is the nature of international politics. At first blush, the U.S. might want the veto on aggression to survive to protect itself from a finding of aggression. But a more practical solution that should protect the U.S. while permitting a referral on a rogue State would be, for example, requiring a finding by twelve or thirteen of the fifteen members that aggression has occurred. When it comes to the ICC, reasonable modifications can be made that will circumvent the veto, allow the Security Council and Court to function efficiently, and still protect the U.S. 


\section{Amendments}

The Rome Statute provided that amendments adopted by the Assembly of States Parties may come into force seven years after the ratification of the Treaty. ${ }^{220}$ There are significant amendments that can be made which the author believes, upon analysis, should encourage the U.S. to both join and strengthen the ICC. Specifically, the U.S. must understand that it can potentially utilize the ICC as an important instrument in its foreign policy against the scourges of terrorism and aggressive war. To meet this potential, the ICC must first amend the Statute to define the terms "terrorism" and "aggressive war" and include them in the list of crimes.

Article 5 of the ICC statute actually includes the crime of aggression, but it will not become an actionable crime unless and until the Preparatory and Select commissions come up with a definition approved by the Assembly of State Parties. ${ }^{221}$ Resolution E adopted at the Rome Conference also recommended that the ICC should "consider the crimes of terrorism and drug crimes with a view to arriving at an acceptable definition and their inclusion in the list of crimes within the jurisdiction of the Court" when the scheduled review conference is held in 2009. ${ }^{222}$

At this time, "frustrating" is the kindest word that the author can use to describe the history of the U.N., the ICC, and the international legal community when it comes to defining such important terms. There are over 100 definitions that have been proposed for the word terrorism. ${ }^{223}$ Despite strong pressure from U.N. Secretary General Kofi Annan to arrive at a definition of the term by the September 14, 2005 World Summit to Celebrate the U.N.'s Sixtieth Anniversary, a core group of thirty-three nations could still not come up with a definition. ${ }^{224}$ There have been no less than eight different proposals from various nations to define the crime of aggression and numerous meetings of the ICC Preparatory Commission, Special Working Groups, and follow-up sessions through 2005 designed to consider these

220. Rome Statute, supra note 93, at art. 123.

221. Rome Statute, supra note 93, at art. 5; Scheffer, supra note 18, at 83.

222. Cherif Bassiouni, The Statute of the Inter national Criminal Court: A Documentary History 104-05 (1998). See also Scheffer, supra note 18, at 83.

223. Donna Arzt, Terrorism and Terrorists, http://jurist.law.pitt.edu/terrorism/terrorism1.htm.

224. Matthew Levitt \& Joshua Prober, UN Definition of Terrorism Remains Elusive, www .washingtoninstitute.org/template. 
formulations. None of these conferences has succeeded. ${ }^{225}$ There has, however, been progress, and success remains within reach.

In reviewing the various proposals and objections, the international community often makes perfect the enemy of the good in their refusal to endorse one definition or another because it does not cover every hypothetical situation or theoretically could include something that was not intended by the framers. This will be observed below when certain proposals and objections are discussed.

Conferees could probably benefit from reviewing the philosophy behind such codifications as the Model Penal Code. ${ }^{226}$ For example, when it came to defining the term "robbery," the drafters of the Model Penal Code agreed that robbery generally means the taking of property belonging to another from the other's person through force or the threat of force. ${ }^{227}$ This outline is utilized in state penal codes throughout the nation. One can imagine, however, situations where a citizen forcibly takes a gun from a man he believes is irrational, a father takes drugs from his son, a pedestrian takes away an angry dog barking at a young child from an owner unable to control the animal, and many other hypotheticals that fit the technical definition of robbery without a guaranteed disqualifying defense. ${ }^{228}$ The fact that these possibilities exist does not prevent the government from defining robbery, prohibiting it, and punishing those who violate the law. This is because citizens rely upon the good faith and common sense of prosecutors, judges, juries, whether of judges or citizens, and appellate courts to screen out situations that do not fall within the original intent of the statute. All of these institutions serve us well.

At some point, the international community needs to understand that the human ability to put down words on a paper will not necessarily provide the perfect definition for every criminal concept. Overlapping institutions composed of people, however, can insure that particular criminal laws are applied only to those who have been intended to be identified, prosecuted, and punished. With this background, the following two sections will examine the current status of the attempts to define terrorism and aggressive war.

225. Roger S. Clark, The Crime of Aggression and the International Criminal Court, Unpublished Paper, Sept. 25, 2005.

226. Model Penal Code (1980).

227. $I d$. at $\S 222.1$. The degree of force and injury can result in the robbery being first, second or third degree.

228. None of these examples meet the duress defense outlined at 2.09 of the Model Penal Code. Whether they could qualify for the defense of necessity listed at 3.05 and 3.06 would depend on an expanded set of facts and circumstances and the ultimate finding of a jury. 


\section{a. Terrorism}

After reviewing the many definitions of terrorism, Daniel Pickard states that the common meaning that consistently reflects the essence of terrorism is "violence ... used for a political/religious objective, in order to affect an intended audience, and thereby to alter an issue of public policy." 229 This is consistent with the U.S. Code and Code of Federal Regulations that define terrorism as "violence ... intended to coerce a civilian population or influence the policy of a government by intimidation or coercion." ${ }^{230}$ Under this definition, President Clinton labeled those who attacked the Khobar towers barracks and the U.S.S. Cole as nothing but "cowardly terrorists." ${ }^{\text {"231 }}$ It could be argued that the bombers in these cases were neither cowards nor terrorists, but misguided enemy soldiers fighting our armed forces establishment. Donna Arzt, Director of the Center for Global Law and Practice at Syracuse University, after conducting her own review of the various definitions, states that the first of "the four or five fundamental elements" of terrorism is that it targets civilian "non-combatants, in order to differentiate terrorism from attacks on military targets, which are outright acts of war." 232

It would appear the Artz definition makes more sense and would garner more support in the international community. The Minutemen shooting at Red Coats from behind trees would be classified as terrorists without a distinction between military and civilian targets, and a definition that categorizes those who attack the military as terrorists plays into the cliché that these people are really only "freedom fighters." On the other hand, it is hard to defend those who attack civilian non-combatants. It is true that Truman would have had to answer for Dresden and Hiroshima if the Axis Powers had won the war, but in the world of the future, we may want to demand that our leaders be held accountable for such attacks. Regardless, a definition focusing on the protection of civilians perfectly conforms with what emerged from the U.N. Panel on Threats, Challenges, and Change in December, 2004. The Panel described terrorism as any action that is "intended to cause death or serious bodily harm to civilians or non-combatants, when the purpose of such

229. Daniel B. Pickard, Legalizing Assassination? Terrorism, the Central Intelligence Agency and International Law, 30 GA. J. INT'L \& COMP. L. 1, 6 (2001).

230. 18 U.S.C. $\S 2331(1) ; 28$ C.F.R. $\S 0.85$. The C.F.R. has slightly different wording but the meaning is the same.

231. See President William Clinton, Remarks About the Saudi Arabia explosion, www.cnn.com/World/9606/25/clinton.remarks (June 25, 1996); John F. Burns \& Stephen Lee Myers, Destroyer Damages, N.Y. Times, Oct. 13, 2001, at A1.

232. See Arzt, supra note 223. 
an act, by its nature or context, is to intimidate a population or compel a government or international organization to do or to abstain from doing any act." 233

Why then could the U.N. not come up with an agreed definition for the Sixtieth Anniversary celebration and, by extension, for the ICC? The reason is that the Arab States objected based on:

The Palestinian position which is the position of prominent Arab and Islamic countries ... that Palestinians are fighting an "occupying force" and are therefore not participating in acts of terrorism - even when those acts include suicide bombings that target civilians. The argument of these countries is carried over to their position of those fighting against Iraqi and U.S. forces in Iraq and Afghani and U.S. forces in Afghanistan. ${ }^{234}$

One can understand anger at "occupation." It might even be tempting to consider authorizing resistance against civilians and military during an illegal occupation. Yet how can the status of occupation be determined? Would the U.N. ever rule quickly and efficiently that a specific territory legitimately belongs to a particular party and not to another? If it did come to a decision, would it be accepted, or combated on the theory that they might change their mind later? Such a provision simply would not work. If the residents of an area believe they are illegally occupied, this still should not justify attacks on civilians and non-combatants. Arab and Western states should now understand this as "from Riyadh to Beirut and from Casablanca to Amman," as well as Iraq, "Arab governments and people are fighting the same war on terrorism that the U.S. and its Western counterparts are fighting." 235 The definition proposed by the U.N. Panel actually appears to provide leeway for attacks on security forces that inevitably accompany civilian occupiers. International authorities should not in any circumstances have to give in and provide more.

At present, Kofi Annan appears to be standing by the position of the U.N. Panel. He recently stated that "the targeting and killing of civilians and non combatants cannot be justified or legitimized by any cause or grievance. A simple, clear statement bringing in moral clarity that maiming and killing civilians is unacceptable regardless of ones cause I think would satisfy all of us. ${ }^{, 236} \mathrm{He}$ is correct, and it is reasonable to expect that the U.N. and ICC will

233. See Levitt \& Prober, supra note 224.

234. $I d$.

235. Levitt \& Prober, supra note 224.

236. BBC News, UN Seeks Definition of Terrorism, July 26, 2005. News.bbc.co.uk/1/hi/ world/americas/4716957 (quoting Kofi Annan). 
agree to a definition within these parameters. As British ambassador Jones Parry stated, "There can be no hiding, no pretext used to justify attacks on innocents . . . . The old dictum that 'one man's terrorist is another man's freedom fighter' is past. One man's terrorist is another man's terrorist, a criminal and too often a murderer." ${ }^{, 237}$

\section{b. Aggressive War}

At the outset of World War I, the German military sent its armies through Belgium to execute their long-planned sweeping flanking movement against the French left in blatant violation of the neutrality treaty that had been signed with that nation in $1839 .^{238}$ After the war, an Allied Commission on Responsibility found that this was a "war of aggression" in violation of specific treaties, but that there was no basis for a criminal charge under existing international law. ${ }^{239}$ In the Kellogg-Briand Pact of 1928, the major powers "condemned recourse to war" and "renounced it as an instrument of national policy," but omitted the inclusion of an explicit proviso stating that waging aggressive war was criminal. ${ }^{240}$ As World War II came to a close and war crimes trials were considered, Colonel William Chandler at the War Department pushed for charges of aggressive war against the Axis. Secretary of War Stimson and President Roosevelt agreed. ${ }^{241}$ When Justice Jackson took over as Chief Counsel, he readily accepted the concept. Indeed, it was a reflection of his own thinking expressed as early as March of 1941 when, in a speech to the Inter American Bar Association in Havana, he rejected the view that all wars are legal, declared that aggressive wars are civil wars against the international community, and accused the Axis Powers of violating their obligations under the Kellogg-Briand Pact. ${ }^{242}$ The Allies subsequently agreed with Jackson and proclaimed in the 1945 London Charter that the main charges against Germany would be war crimes, crimes against humanity, and "Crimes Against Peace, namely ... waging a war of aggression, or a war in violation of international treaties." ${ }^{243}$

237. Patrick Goodenough, Terrorism Definition Again Causing Problems at UN, CNS news, Aug. 31, 2005, www.cnsnews.com/ViewForeign Bureaus.asp/Foreign Bureaus Archive/200508 (quoting Jones Parry).

238. TAYLOR, supra note 46, at 12.

239. Id. at 15.

240. Id. at 37 .

241. Id. at 37-38.

242. Id. at 44 .

243. Charter of the International Military (1945) (“London Charter”), reprinted in TAYLOR, supra 
One searches in vain, however, through the preliminary discussions, charges, and judgment at Nuremberg for concrete elements of exactly what constitutes aggression or the charged crime of aggressive war. Those who lived with Hitler and Tojo knew what aggression was and may not have felt as compelled to explain it as we are today. As Professor Roger S. Clark stated,

At Nuremberg and Tokyo, there was no great need to define what was meant by aggression. It was sufficient to adopt something like Justice Stewart's approach to dirty books. That is to say, we know that disgusting stuff when we see it, and in particular this is what the Germans and Japanese had done. ${ }^{244}$

There seems to have been some agreement that the phrase "aggressive war" involved an invasion, occupation, and a violation of a treaty pledge such as the Kellogg-Briand pact. Thus, Germany's takeover of most of Czechoslovakia and Austria through a combination of military intimidation and diplomacy was simply "aggression," but the invasion and occupation of Poland was "aggressive war." 245 Hermann Goering and the lead Nuremberg defendants were convicted of conspiracy to plan aggressive war and waging aggressive war. A precedent was thus established, even if the legal basis was not exactly clear.

After World War II, the U.N. embarked on a twenty-year quest to define and prohibit "aggression" by a State. The result was the General Assembly's 1974 passage of Resolution 3314. This resolution named acts by a State that could constitute aggression such as invasion and occupation, bombardment, blockading, and "other acts" (that the Security Council may determine) constitute aggression under the Charter. ${ }^{246}$ Resolution 3314 provides that the use of such armed force is prima facie evidence of aggression, but suggests that the State can then justify its actions before the Security Council on the basis of self-defense, humanitarian intervention, or other grounds. ${ }^{247}$ The Resolution also does not criminalize individual conduct or set forth elements of what may constitute the crime of "aggression" or "aggressive war." The actions listed by 3314 are probably at best markers that may be utilized in attempting to arrive at such a legal definition.

\footnotetext{
note 46 , at $645-53$

244. Clark, supra note 225.

245. TAYLOR, supra note 46, at 575 .

246. G.A. Res. 3314(XXIX), U.N. Doc. A/9631 (1975).

247. Clark, supra note 225.
} 
Article 5, paragraph 1 of the Rome Statute of the ICC named "aggression" as one of the four crimes within the jurisdiction of the Court. ${ }^{248}$ Resolution F of the Rome Conference instructed the Preparatory Commission to "prepare proposals for a provision on aggression, including the definition of Elements of Crimes of Aggression and conditions under which the International Criminal Court shall exercise its jurisdiction with regard to this crime."249 The new provision must be "consistent with the relevant provisions of the Charter of the United Nations." ${ }^{250}$ The Preparatory Commission, however, could not agree on a definition before it expired in 2002. It has submitted a Coordinator's Discussion paper listing various options that have since been worked on by a Special Working Group of the Assembly of State Parties of the Court. ${ }^{251}$

The many variations and nuances of this ongoing process are explained by Professor Clark, the representative of Samoa on the Special Working Group, in his recent paper, "The Crime of Aggression and the International Criminal Court." 252 It is beyond the scope of this article to attempt to detail all of the potential options being considered. The essence, however, is that the Coordinator's Discussion paper set forth a definition of aggression that states:

1. For the purpose of the present Statute, a person commits a "crime of aggression" when, being in a position effectively to exercise control over or to direct the military or political action of as State, that person intentionally and knowingly orders or participates actively in the planning, preparation, initiation or execution of an act of aggression which, by its character, gravity and scale, constitutes a flagrant violation of the Charter of the United Nations.

2. For the purposes of paragraph 1, "act of aggression" means an act referred to in United Nations General Assembly Resolution 3314 of 14 December 1974, which is determined to have been committed by the State concerned.

There are important proposals to add to the first section: a. "such as" or b. "amounts to," "a war of aggression or an act which has the object or the result of establishing a military occupation of, or annexing, the territory of another State or part thereof." There is also a proposal to leave this section intact with no additions.

248. Rome Statute, supra note 93, at art. 5(1).

249. Final Act of the United Nations Diplomatic Conference of Plenipotentiaries on the Establishment of an International Criminal Court, Annex I, Resolution F, paragraph 7, U.N. Doc. A/CONF. $183 / 10$ (1998) at 8-9.

250. Rome Statute, supra note 93, at art. 5(1).

251. Clark, supra note 225.

252. Id. 
As to the second section, there are proposals that the determination of an "act of aggression" must be made by the Security Council. Others suggest that, if the Security Council does not act, the General Assembly, the International Court of Justice, or the ICC itself may make the determination. ${ }^{253}$

What is clear from what has been agreed upon is that: 1) the crime of aggression would be a leadership crime applying only to those with effective control, 2) that the crime of aggression must be on such a scale as to constitute a flagrant violation of the Charter, 3) that the defendant must act intentionally and knowingly, but apparently would have a mistake of law or fact defense and 4) that because Article 5 requires that the definition be in accordance with the Charter, there will likely have to be a finding of aggression by the Security Council, General Assembly, the International Court of Justice, or the ICC as a precondition of prosecution.

As Professor Clark notes, because of the flexibility of 3314 and the interaction of the ICC with other organs of the U.N. in the definition of aggression, the offense as currently outlined is somewhat indeterminate for a criminal penal violation. Choices will also have to be made between the various options. The author prefers the options that include invasion and permanent occupation or annexation, as these would closely equate "aggression" and "aggressive war" and reflect the original meaning of the concept of aggressive war as demonstrated by the blatant and outrageous invasions of Poland, the Philippines, and Kuwait. Regardless, progress has definitely been made, there are reasonable options from which to choose, and criminal attorneys can insure the offense is solidified to meet criminal law standards. There is reason to be optimistic that what needs to be done can be accomplished.

The U.S. should have nothing to lose and much to gain from the inclusion of these provisions within the jurisdiction of the ICC. Those who are concerned that the U.S. would be charged with a crime for our actions in Iraq, for example, should be aware that, when the German Federal prosecutor was asked to determine whether the U.S. action was aggressive war because of German legal requirements related to assistance, he had no problem finding that the invasion was not criminal as it was carried out in an attempt to enforce Security Council resolutions. In light of the atrocities of Saddam Hussein, it was also potentially a permissible humanitarian intervention. ${ }^{254}$ The essence

253. Id.

254. Claus Kress, The German Chief Federal Prosecutor's Decision Not To Investigate The Alleged Crime of Preparing Aggression Against Iraq, 2 J. INT'L CRIM. JUST. 245, 261-64 (2004). 
of this offense, as indicated in the proposed additions to Section One, is really invasion, occupation, and annexation. The leaders of China, North Korea, Iran, and potential rogue states would need to take note of its provisions. But, although the U.S. has been perhaps too muscular for the sensibilities of many in the international community in the last twenty-five years, no one can justifiably claim that the purpose of our military action was to permanently occupy and annex territory. Indeed, the people of Grenada, Panama, Yugoslavia, Kuwait, Afghanistan, and Iraq can all readily attest that the U.S., unlike Germany and Japan, has sought as quickly as possible to turn over the government of conquered territory to those who are elected by their own people.

\section{Conclusion}

There are serious flaws in current single nation and ad hoc attempts to avenge human rights violations and war crimes. The U.N. and the vast majority of nations now clearly recognize the need for a permanent international criminal court. U.S. opposition to this Court is obviously contrary to our history as the world's leader in defense of human rights. Moreover, the public objections expressed by U.S. officials and congressmen to the Court appear, for the most part, to be based on misunderstandings and unlikely hypotheticals. To the extent they have merit, fairly minor adjustments in ICC procedures could correct the problem.

More importantly, it is vital to understand that our opposition to the ICC is against our best interests. This international institution and international criminal law have arrived, and it is far better that the U.S. controls the process in the future and use it to its advantage then stand alone as its own rogue state against ninety-nine civilized nations. When we decide to join the ICC, we will not see the international community and the Court as the enemy, nor will others perceive us in this manner. We will instead recognize the great potential of the Court to provide stability to the world and to serve as a channel of unified action against terrorists, aggressors, and tyrants. Those who consider themselves nationalists, moderates, or members of the right wing of American politics need to consider these arguments in the years to come. If they do, the author is confidant that not only will the U.S. join the ICC, but it will emerge as its leader and greatest advocate. 